\title{
INTERPRETING LEGISLATIVE INACTION
}

\author{
William N. Eskridge, Jr.*
}

There is a longstanding debate in the theory of statutory interpretation over what meaning, if any, can be attributed to the legislature's failure to do something. Issues of "legislative inaction" often arise in cases where the Supreme Court considers the validity of an administrative or judicial interpretation of a statute and the argument is made that the interpretation must be accepted because Congress has acquiesced in it by not overruling it, has ratified it by reenacting the statute, or at some point was presented with a formal bill or amendment embodying an alternative interpretation and rejected it. ${ }^{1}$ The Court has grappled with such arguments since the nineteenth century, ${ }^{2}$ oftentimes finding inaction arguments persuasive but other times finding them unappealing. The debate within the Court over the significance of legislative inaction has intensified in the last two Terms, ${ }^{3}$ in large

* Associate Professor of Law, Georgetown University Law Center. - Ed.

Many thanks to Alexander Aleinikoff, Robert Drinan, Daniel Farber, Philip Frickey, Michael Froomkin, Lawrence Marshall, Dennis Patterson, and Richard Posner for generous and constructive comments on an earlier draft of this article. Dean Robert Pitofsky of the Georgetown University Law Center provided intellectual encouragement and financial support for my work on this article, for which I am grateful. I appreciate the research assistance provided by Christopher Williams, Kathleen Blanchard, and Robert Schoshinski.

1. As the quotation marks suggest, "legislative inaction" is a term of art widely used in Supreme Court opinions and law review articles for the phenomena described in the text. But, obviously, for each phenomenon - acquiescence, reenactment, rejection - Congress (or a subgroup in Congress) is engaged in "action" as well. And the phenomena discussed in this article do not exhaust the occasions for which Congress' failure to act has doctrinal significance.

2. See, e.g., United States v. Dickson, 40 U.S. (15 Pet.) 141, 161-62 (1841) (Story, J.).

3. The main legislative inaction decisions handed down in the 1987 Term were Communications Workers of Am. v. Beck, 108 S. Ct. 2641, 2654-55 (1988) (rejecting argument based upon rejected proposals; but see $108 \mathrm{~S}$. Ct. at 2663-64 (Blackmun, J., concurring in part and dissenting in part)); Pierce v. Underwood, $108 \mathrm{~S}$. Ct. 2541, 2551 (1988) (accepting reenactment argument; but see $108 \mathrm{~S}$. Ct. at 2555 (Brennan, J., concurring in part and concurring in the judgment)); Boyle v. United Technologies Corp., 108 S. Ct. 2510 (1988) (rejecting argument based on rejected proposals; but see $108 \mathrm{~S}$. Ct. at 2519-20 \& n.1 (Brennan, J., dissenting)); Monessen S.W. Ry. v. Morgan, 108 S. Ct. 1837, 1843-44 (1988) (accepting acquiescence and rejected proposal arguments; but see $108 \mathrm{~S}$. Ct. at 1848-49 (Blackmun, J., concurring in part and dissenting in part)); Landers v. National R.R. Passengers Corp., 108 S. Ct. 1440, 1442 (1988) (accepting rejected proposal argument); Schneidewind v. ANR Pipeline Co., 108 S. Ct. 1145, 1153-54 (1988) (rejecting argument based upon rejected proposals); Arkansas Best Corp. v. Commissioner, $108 \mathrm{~S}$. Ct. 971, 977 n.7 (1988) (rejecting acquiescence argument); Norwest Bank Worthington v. Ahlers, 108 S. Ct. 963, 968 (1988) (accepting rejected proposal argument); K Mart Corp. v. Cartier, Inc., $108 \mathrm{~S}$. Ct. 950, 958-59 (1988) (accepting rejected proposal argument).

The main legislative inaction decisions handed down in the $1986 \mathrm{Term}$ were Tanner v. United States, 107 S. Ct. 2739, 2748-50 (1987) (accepting rejected proposal argument; but see $107 \mathrm{~S}$. Ct. at 2757-58 (Marshall, J., concurring in part and dissenting in part)); Shearson/American Express, Inc. v. McMahon, 107 S. Ct. 2332, 2343 (1987) (rejecting acquiescence argument; but see 
part because of the appointment of Justice Antonin Scalia, who has articulated sophisticated arguments against giving positive meaning to legislative inaction.

These arguments may be tested early in the 1988 Term. The Court has requested briefs in Patterson v. McLean Credit Union, 4 to address the question whether the Court's decision in Runyon v. McCrarys should be overruled. Runyon interpreted section 1 of the Civil Rights Act of 1866 (now section 1981$)^{6}$ to prohibit private discrimination in contractual relations. In Patterson, four Justices sharply dissented from the request for further briefs on what they considered a settled question. The dissenting Justices relied, in part, upon Congress' failure to overturn the Court's line of decisions interpreting the 1866 Act to cover private discrimination. ${ }^{7}$ The briefs for petitioner and several supporting amici strongly rely on several legislative inaction arguments. ${ }^{8}$ Patterson, therefore, presents the Court with a clear opportunity to make sense of its legislative inaction precedents, perhaps with an eye on Justice Scalia's critique.

Patterson also provides commentators with an opportunity to revisit the Court's theory and practice in legislative inaction cases. Traditionally, scholars have been skeptical of the Court's inconsistent use of legislative inaction and have argued that "almost no reliable inference of [legislative] intent could be drawn" from the legislature's silence or inaction. ${ }^{9}$ However, there has also been some scholarly

107 S. Ct. at 2348 (Blackmun, J., concurring in part and dissenting in part)); United States v. Johnson, 107 S. Ct. 2063, 2066 \& n.6 (1987) (accepting acquiescence argument; but see $107 \mathrm{~S}$. Ct. at 2075 (Scalia, J., dissenting)); Johnson v. Transportation Agency, Santa Clara County, 107 S. Ct. 1442, 1450-51 n.7 (1987) (accepting acquiescence argument; but see $107 \mathrm{~S}$. Ct. at 1472-73 (Scalia, J., dissenting)); INS v. Cardoza-Fonseca, 107 S. Ct. 1207, 1218-19 (1987) (accepting rejected proposal argument; but see 107 S. Ct. at 1230 (Powell, J., dissenting)).

4. 108 S. Ct. 1419 (1988) (per curiam).

5. 427 U.S. 160 (1976).

6. 42 U.S.C. $\$ 1981$ (1982): "All persons within the jurisdiction of the United States shall have the same right in every State and Territory to make and enforce contracts, to sue, be parties, give evidence, and to the full and equal benefit of all laws and proceedings for the security of persons and property as is enjoyed by white citizens, and shall be subject to like punishment, pains, penalties, taxes, licenses, and exactions of every kind, and to no other." Part of the debate within the Court in Runyon was whether $\S 1981$ was taken from the 1866 Act. I am assuming in this article that it was, as the Court held, but $I$ have undertaken no independent investigation of this matter. n.11).

7. Patterson, 108 S. Ct. at 1422 (Blackmun, J., dissenting) (citing Runyon, 427 U.S. at $174 \&$

8. The main briefs making legislative inaction arguments are Brief for Petitioner on Reargument at 71-100, Patterson (No. 87-107) [hereinafter Petitioner's Brief]; Brief of 66 Members of the United States Senate and 118 Members of the United States House of Representatives as Amici Curiae in Support of Petitioner at 20-28 [hereinafter Congress' Brief]; Brief on Reargument for the Lawyers' Committee for Civil Rights Under Law as Amicus Curiae in Support of Petitioner at 11-16 [hereinafter Lawyers' Committee Brief].

9. R. Dickerson, The INTERPREtation AND APpliCation of StatUTES 181 (1975); see 
defense of a limited use of legislative inaction as an interpretive tool. ${ }^{10}$

The purpose of this article is to contribute to the doctrinal and theoretical debate about the meaning of legislative inaction for the statutory interpreter. I hope to make three contributions. Part I offers a doctrinal starting point for analyzing legislative inaction issues generally and those in Patterson in particular. Three related doctrines emerge from the Court's past treatment of legislative inaction issues: (1) the "acquiescence rule," positing that if Congress does not overturn a judicial or administrative interpretation it probably acquiesces in it; (2) the "reenactment rule," which posits that a reenactment of the statute incorporates any settled interpretations of the statute by courts or agencies; and (3) the "rejected proposal rule," which posits that proposals rejected by Congress are an indication that the statute cannot be interpreted to resemble the rejected proposals. These rules are not inevitably followed, though. In some cases, the Court finds great meaning in "positive inaction."11 In other cases the Court finds such an inquiry nothing more than "the pursuit of a mirage."12 Still, the reasoning of the cases seeks, with some success, to suggest coherence. Generally, when the Court finds meaning in Congress' inaction, it points to specific legislative consideration of the issue and, either implicitly or explicitly, indicates that Congress' failure to act bespeaks a probable intent to reject the alternative(s).

Thus, I think there is a little more coherence to the Court's approach to legislative inaction than most commentators have found. The Court's reasoning is an intelligent, practical effort to fit the legislature's inaction into what the Court perceives as its general mandate to respect legislative intent when it interprets statutes. The question remains, however, whether legislative inaction really does tell the Court, or us, anything about legislative intent in these cases. The answer depends very much on what one means by "legislative intent." Part II argues that if one means the actual collective will or desire of the en-

H. Hart \& A. Sacks, The Legal Process: Basic Problems in the Making and ApplicaTION OF LAW 1394-1401 (tentative ed. 1958); Dickerson, Statutory Interpretation: Dipping into Legislative History, 11 HoFstRA L. REv. 1125, 1133 (1983); Eskridge, Overruling Statutory Precedents, 76 GEO. L.J. 1361, $1402-09$ (1988); Freund, Interpretation of Statutes, 65 U. PA. L. REv. 207, 214-15 (1917); Grabow, Congressional Silence and the Search for Legislative Intent: $A$ Venture into "Speculative Unrealities," 64 B.U. L. REV. 737 (1984); Note, Congressional Silence \& the Supreme Court, 27 IND. L.J. 288 (1952).

10. See 2A N. Singer, Sutherland's STATutory Construction $\$ 49.10$ (4th ed. 1984); Tribe, Toward a Syntax of the Unsaid: Construing the Sounds of Congressional and Constitutional Silence, 57 IND. L.J. 515 (1982); Froomkin, The Sound of One House Clapping: Theories of Congressional Acquiescence (July $1988 \mathrm{draft}$ )(forthcoming); see also Horack, Congressional Silence: A Tool of Judicial Supremacy, 25 TEXAS L. REv. 247 (1947).

11. Flood v. Kuhn, 407 U.S. 258, 283 (1972).

12. Scripps-Howard Radio, Inc. v. FCC, 316 U.S. 4, 11 (1942). 
acting legislature, legislative inaction should rarely be given much, or any, weight. Assuming this view of legislative intent, I agree with and elaborate upon Justice Scalia's critique of the Court's frequent invocation of legislative inaction.

Part III argues that the cases make more sense if we read them as decisions about presumed, rather than actual, legislative intent. Like other legal doctrines drawing inferences from inaction, the various legislative inaction doctrines are policy presumptions having this general message: When Congress enacts a statute that implicitly or explicitly delegates lawmaking authority to courts, agencies, or the executive, "building block interpretations" by the courts, agencies, or executive are presumptively correct if Congress does not disturb them. A building block interpretation of the statute is one that is authoritative or settled and has given rise to public or private reliance interests. Hence, there is no presumption of correctness for interpretations that are not authoritative (e.g., a single lower court decision), or have not been treated as reliable building blocks for private conduct or public policy. The presumption of correctness can be rebutted by clear evidence that the building block interpretation is inconsistent with the statutory language and policies.

At first blush, the proposition staked out in Part III seems like an unusual approach to statutory interpretation, but I argue that its presumption is quite consistent with other widely accepted practices and doctrines in statutory interpretation, especially clear statement rules. More importantly, a presumption or clear statement approach has the substantial virtue of explaining the Court's own legislative inaction precedents better than the "actual intent" or "collective will" proposition does. While I think my explanation of the legislative inaction cases describes what the Court is doing pretty well, I have several normative problems with the cases. My general problem is that the cases overemphasize what I call "vertical continuity," that is, the perseverance of an interpretation over time. And the cases underemphasize "horizontal continuity," that is, the coherence of rules and policies at any given time. As the Court applies the lessons of the legislative inaction cases, it ought to be mindful of the need for law to evolve. Patterson is a classic case for application of the presumed intent of the case law and is not subject to this normative problem.

\section{The Supreme Court's Legislative Inaction CaSes AND Their Legal Process Reasoning}

The legislative inaction cases decided by the Supreme Court in the post-World War II era can be generally divided into three categories: 
the "acquiescence cases," in which the Court concludes that Congress' failure to overturn a judicial or administrative interpretation is evidence that Congress has acquiesced in that interpretation of the statute; the "reenactment cases," where the acquiescence argument is buttressed by reenactment of the interpreted statute without material change; and the "rejected proposal cases," in which the Court infers from the rejection of a bill or amendment by Congress, or by a chamber or committee of Congress, that an interpretation similar to the rejected proposal is excluded from the statute. There are also many cases where the Court has refused to draw these inferences from Congress' failure to respond, its reenactment of a statute, or its rejection of a proposal. Three appendices to this article list post-1961 Supreme Court decisions accepting or refusing to accept these arguments. Overall, the cases suggest that the Court does not lightly rely upon inaction as the primary basis for its decisions in statutory interpretation cases and that the Court will usually justify reliance on legislative inaction by pointing to Congress' awareness of the interpretative issue, and some deliberation about it. In contrast, when the Court refuses to credit significance to legislative inaction, it will usually point to Congress' inattention to the issue. In this part, I shall survey each line of cases and explain how they fit together by using the legal process rationales generally suggested by the Court. The discussion of each rule (acquiescence, reenactment, rejected proposal) will conclude with its application in Patterson, for all three types of inaction arguments can reasonably be made in that case.

\section{A. The Acquiescence Rule}

The leading acquiescence case is Apex Hosiery Co. v. Leader, ${ }^{13}$ which held that labor unions are not wholly excluded from coverage of the Sherman Act. Judicial interpretations of the antitrust laws had originally extended those laws to cover union activity in a broad range of cases. Although legislative amendments to the statutes narrowed that range, Apex Hosiery held not only that Congress had not overruled the early cases, but that Congress had fortified them. "The long time failure of Congress to alter the Act after it had been judicially construed . . . is persuasive of legislative recognition that the judicial construction is the correct one," the Court concluded. "This is the more so where, as here, the application of the statute to labor unions has brought forth sharply conflicting views both on the Court and in Congress, and where after the matter has been fully brought to the

13. 310 U.S. 469 (1940). 
attention of the public and the Congress, the latter has not seen fit to change the statute."14 The Apex Hosiery principle shows up in many Supreme Court decisions interpreting statutes, though the Court typically exercises caution when invoking its acquiescence rule.

A recent application of the acquiescence rule is Flood v. Kuhn, ${ }^{15}$ which also involved interpretation of the Sherman Act. In Federal Baseball Club v. National League, ${ }^{16}$ the Court held that baseball in the 1920s was not subject to the Sherman Act because its "exhibitions" were "purely state affairs" and not directly involved in interstate commerce, as required by the Act. ${ }^{17}$ In the ensuing decades, of course, baseball grew into a highly popular interstate business. Yet the Court in Toolson v. New York Yankees, Inc. ${ }^{18}$ refused to overrule Federal Baseball, in part because "Congress has had the ruling under consideration but has not seen fit to bring such business under these laws by legislation having prospective effect."19 In the 1950s and 1960s, after Toolson, baseball continued its interstate growth, adding lucrative television contracts to its other interstate dimensions. This made Federal Baseball an increasingly anomalous opinion - especially after the Court applied the Sherman Act to other professional sports. ${ }^{20}$ The Court in Flood again reconsidered Federal Baseball and, again, refused to overrule it, primarily relying on the "positive inaction" of Congress. $^{21}$ In particular, the Court noted that between 1957 and 1965 more than fifty bills were introduced to deal with the issue; that even after extensive consideration and hearings (two of the bills passed one house of Congress), none of the bills became law; and that most of the bills would have expanded rather than contracted antitrust immunity. ${ }^{22}$ Based upon this evidence, the Court concluded that "Congress as yet has had no intention to subject baseball's reserve system to the reach of the antitrust statutes."23

The precept that Congress by its positive inaction can incorporate a judicial interpretation into statutory law is sometimes cited by the

14. 310 U.S. at $488-89$.

15. 407 U.S. 258 (1972).

16. 259 U.S. 200 (1922).

17. 259 U.S. at 208.

18. 346 U.S. 356 (1953) (per curiam).

19. 346 U.S. at 357.

20. See Radovich v. National Football League, 352 U.S. 445 (1957); United States v. International Boxing Club, 348 U.S. 236 (1955).

21. 407 U.S. at 283.

22. 407 U.S. at $281-82$.

23. 407 U.S. at 283; see 407 U.S. at $283-84$ ("Congress, by its positive inaction, has allowed those decisions to stand for so long and, far beyond mere inference and implication, has clearly evinced a desire not to disapprove them legislatively."). 
Court when it refuses to overrule its own statutory precedents. ${ }^{24}$ And sometimes the Court will incorporate settled lower court statutory interpretations into the statute, based upon Congress' failure to overrule them after they have been brought to Congress' attention. ${ }^{25}$ The Apex Hosiery rule is also applicable to agency and executive interpretations of statutes, and there are a substantial number of cases relying on congressional acquiescence in nonjudicial interpretations.

Bob Jones University v. United States ${ }^{26}$ is a significant acquiescence case for executive department interpretations. The Court held that the income tax exemption for "[c]orporations ... organized and operated exclusively for religious, charitable . . . or educational purposes"27 does not apply to educational institutions that discriminate on the basis of race. The primary ground for the Court's holding was that permitting a tax exemption for educational institutions discriminating on the basis of race would be fundamentally at odds with our national policy against racial discrimination and the statute's overall purpose. ${ }^{28}$ In support of its decision, the Court emphasized legislative acquiescence in this interpretation of the statute, first voiced by the Internal Revenue Service (IRS) in 1970. The Court observed: "Nonaction by Congress is not often a useful guide, but the nonaction here is significant."29

To begin with, the IRS position became the focus of prolonged public debate and congressional hearings (the first of which was held only a month after the IRS announced the interpretation in 1970). At least thirteen bills were introduced in Congress to overturn the IRS interpretation, yet none even emerged from committee, even though other amendments to the charitable exemption provision were passed in 1976. "It is hardly conceivable that Congress . . . was not abundantly aware of what was going on. In view of its prolonged and acute awareness of so important an issue, Congress' failure to act on the bills

24. See, e.g., United States v. Johnson, 107 S. Ct. 2063, 2066 \& n.6 (1987); Johnson v. Transportation Agency, Santa Clara County, 107 S. Ct. 1442, 1450 n.7 (1987); Square D Co. v. Niagara Frontier Tariff Bureau, 476 U.S. 409, 420, 423-24 (1986); Southern Motor Carriers Rate Conf. Inc. v. United States, 471 U.S. 48, 55 n.18 (1985).

25. See Monessen S.W. Ry. v. Morgan, 108 S. Ct. 1837, 1843-44 (1988); Lindahl v. Office of Personnel Management, 470 U.S. 768, $782-88$ (1985); Herman \& MacLean v. Huddleston, 459 U.S. 375, 384-86 (1983); Merrill Lynch, Pierce, Fenner \& Smith, Inc. v. Curran, 456 U.S. 353, 378-82 (1982); Bloomer v. Liberty Mut. Ins. Co., 445 U.S. 74 (1980); Blue Chip Stamps v. Manor Drug Stores, 421 U.S. 723, 733 (1975); Gulf Oil Corp. v. Copp Paving Co., 419 U.S. 186, 200-01 (1974); Blau v. Lehman, 368 U.S. 403, 411-13 (1962).

26. 461 U.S. 574 (1983).

27. I.R.C. $\$ 501(c)(3)(1982)$.

28. 461 U.S. at 585-96.

29. 461 U.S. at 600 ; see 461 U.S. at 600 ("Ordinarily, and quite appropriately, courts are slow to attribute significance to the failure of Congress to act on particular legislation."). 
proposed on this subject provides added support for concluding that Congress acquiesced in the IRS rulings." 30 Most importantly, the Court emphasized that "Congress affirmatively manifested its acquiescence" by enacting a new provision that denies tax-exempt status to social clubs discriminating on the basis of race. ${ }^{31}$ The new provision filled a gap in the IRS anti-discrimination policy, created when a three-judge court held that discriminatory social clubs could still receive tax exemptions. And the committee reports for the amendment strongly endorsed the IRS policy against racial discrimination, stating that "discrimination on account of race is inconsistent with an educational institution's tax exempt status." ${ }^{32}$ The Court believed this language all but endorsed the IRS rule set forth in $1970 . .^{33}$

As in Bob Jones, the Court will often find that congressional failure to disapprove of executive department regulations, while "not dispositive ... strongly implies that the regulations accurately reflect congressional intent." ${ }^{34}$ The inference is even stronger in the foreign affairs arena, where the executive has special competence; the Court will routinely infer legislative approval of executive practices, where "Congress has consistently failed to object to [such interpretations or practices] . . . even when it has had an opportunity to do so." 35 The Court draws similar inferences from interpretations by independent agencies. It will attribute significance to legislative inaction "once an agency's statutory construction has been 'fully brought to the attention of the public and the Congress,' and the latter has not sought to alter that interpretation although it has amended the statute in other respects." 36

30. 461 U.S. at $600-01$.

31. 461 U.S. at 601 (citing Act of Oct. 20, 1976, Pub. L. No. 94-568, 90 Stat. 2697 (1976) (codified at 26 U.S.C. § 501(i) (1982))).

32. S. ReP. No. 1318, 94th Cong., 2d Sess. 8 n.5, reprinted in 1976 U.S. CODE CONG. \& ADMIN. NEWS 6051, 6058 \& n.5.

33. 461 U.S. at 601-02; see also 461 U.S. at $607 \&$ n.2 (Powell, J., concurring in part and concurring in the judgment).

34. Grove City College v. Bell, 465 U.S. 555, 568 (1984); see also School Bd. v. Arline, 107 S. Ct. 1123, 1126-27 (1987) (HHS); Wright v. City of Roanoke Redevelopment \& Hous. Auth., 107 S. Ct. 766, 774 (1987) (HUD); North Haven Bd. of Educ. v. Bell, 456 U.S. 512, 535 (1982) (HEW); Saxbe v. Bustos, 419 U.S. 65, 73-74 (1974) (INS). Bob Jones is an example of the special deference given to IRS interpretations of the Code that are not overturned by Congress. See also Commissioner v. Engle, 464 U.S. 206, 225 (1984) (reenactment case); Alessi v. Raybestos-Manhattan, Inc., 451 U.S. 504, 519-20 (1981); Don E. Williams Co. v. Commissioner, 429 U.S. 569, 576-77 (1977) (reenactment case).

35. Dames \& Moore v. Regan, 453 U.S. 654,682 n.10 (1981) (a leading case); see also Haig v. Agee, 453 U.S. 280, 291-92 (1981); Zemel v. Rusk, 381 U.S. 1, 11 (1965).

36. United States v. Rutherford, 442 U.S. 544, 554 n.10 (1979) (quoting Apex Hosiery, 310 U.S. at 489) (a leading case); see also United States v. Riverside Bayview Homes, Inc., 474 U.S. 121, 137 (1986) (Corps of Engineers); NLRB v. Hendricks County Rural Elec. Membership Corp., 454 U.S. 170, 187-88 (1981); United States v. Clark, 454 U.S. 555, 564-66 (1982) (Civil 
While the Apex Hosiery acquiescence rule has been very widely invoked by the Court, there are almost as many decisions expressly refusing to follow the rule. The leading case is Helvering v. Hallock, ${ }^{37}$ which overruled several Supreme Court precedents interpreting an estate tax provision of the Internal Revenue Code. The acquiescence argument in the case was a strong one: Not only had Congress failed to change the provision to overrule those precedents, but it had amended related estate tax provisions, including other subsections of the same Code section, to respond to other Supreme Court precedents. ${ }^{38}$ Nonetheless, the Court overruled the precedent. "It would require very persuasive circumstances enveloping Congressional silence to debar this Court from re-examining its own doctrines. To explain the cause of non-action by Congress when Congress itself sheds no light is to venture into speculative unrealities." 39

When the Court follows Hallock, it generally pays lip service to the acquiescence rule and emphasizes procedural reasons why legislative inaction is not particularly cogent. One strategy is to show that Congress was not aware of the judicial or administrative interpretation and, therefore, could not be charged with any form of approval by its failure to overturn it. For example, in Zuber v. Allen, ${ }^{40}$ the Court rejected the Department of Agriculture's apparent interpretation of the Agricultural Milk Marketing Act of 1937, to exempt "nearby farmers" from the uniform pricing contemplated by the Act. The Court had some nasty things to say about the inaction argument but confined them to a footnote. ${ }^{41}$ Its main reason for rejecting the argument was the ambiguity of the Department's position and the clear evidence that, whatever the Department's position was, Congress had never been made aware of it nor been given a meaningful chance to express disapproval.42 There are numerous cases where the Court follows this first, highly popular, strategy of explaining away legislative inaction by reference to Congress' ignorance of the prior interpreta-

Service Commission); CBS, Inc. v. FCC, 453 U.S. 367, 383-85 (1981); EEOC v. Associated Dry Goods Corp., 449 U.S. 590, 600 n.17 (1981); Board of Governors of Fed. Res. Sys. v. First Lincolnwood Corp., 439 U.S. 234, 245-48 (1978); Chemehuevi Tribe v. FPC, 420 U.S. 395, 40910 (1975); NLRB v. Bell Aerospace Co., 416 U.S. 267, 287-88 (1974); Red Lion Broadcasting Co. v. FCC, 395 U.S. 367, 381 (1969).

37. 309 U.S. 106 (1940).

38. See 309 U.S. at 130-32 (Roberts, J., dissenting).

39. 309 U.S. at 119-20 (majority opinion).

40. 396 U.S. 168 (1969).

41. 396 U.S. at 185 n.21.

42. See 396 U.S. at 192-94. 
tion $^{43}$ or to the lack of a clear line of interpretation by an agency or the courts. ${ }^{44}$

A second strategy around the acquiescence rule has been to posit that Congress, even though it has not formally overruled the administrative or judicial interpretation, has acted as though the interpretation were not the settled one. An important case is Monell $v$. Department of Social Services, ${ }^{45}$ which overruled the Court's earlier decision immunizing local governments from lawsuits pursuant to section 1983.46 Congress had considered several bills to overrule the precedent, but the Court rejected any acquiescence argument, in part because it would be "inconsistent with recent expressions of congressional intent." 47 That is, when Congress passed laws authorizing grants to school boards and other local governmental bodies to assist in compliance with federal court decrees, it tacitly recognized that school boards and other local bodies were often defendants in section 1983 actions. ${ }^{48}$ And the Senate report to the Civil Rights Attorneys Fees Awards Act of 1976 (the Fees Act) ${ }^{49}$ explicitly recognized that "defendants in [section 1983] cases are often State or local bodies" and that those defendants ought in appropriate cases to pay counsel fees for prevailing plaintiffs. ${ }^{50}$

A third strategy for avoiding the acquiescence rule is to contend that subsequent legislative inactivity cannot ratify a clearly erroneous prior interpretation. A significant recent case illustrating this exception is Aaron v. SEC. ${ }^{51}$ The issue was whether the SEC had to establish scienter as a necessary element in an injunction action to enforce the anti-fraud rule. The Court held that scienter was necessary, based upon the reasoning of Ernst \& Ernst v. Hochfelder, ${ }^{52}$ which had held that a private party seeking damages under the anti-fraud rule had to prove scienter. This seems logical enough, but the SEC had a particu-

43. See, e.g., Rowan Cos. v. United States, 452 U.S. 247, 260, 262 n.15 (1981); Morton v. Ruiz, 415 U.S. 199, 212-30 (1974); Toussie v. United States, 397 U.S. 112, 120 (1971).

44. See, e.g., Shearson/American Express, Inc. v. McMahon, 107 S. Ct. 2332, 2343 (1987); United States v. Mendoza-Lopez, 107 S. Ct. 2148, 2154 (1987); Rowan Cos. v. United States, 452 U.S. 247, 258-62 (1981); Rodriguez v. Compass Shipping Co., 451 U.S. 596, 614-15 (1981).

45. 436 U.S. 658 (1978).

46. See Monroe v. Pape, 365 U.S. 167 (1961).

47. 436 U.S. at 696.

48. See 436 U.S. at $696-97$ \& n.63.

49. Pub. L. No. $94-559, \S 2,90$ Stat. 2641 (1976) (codified as amended at 42 U.S.C. $\S 1988$ (1982)).

50. S. REP. No. 1011, 94th Cong., 2d Sess. 5 (emphasis added), reprinted in 1976 U.S. CODE Cong. \& ADMin. NEwS 5908, 5913; see Monell, 436 U.S. at 697-99.

51. 446 U.S. 680 (1980).

52. 425 U.S. 185 (1976). 
larly strong legislative inaction argument. Namely, both before and after Hochfelder, the SEC and lower federal courts had interpreted the statute not to require scienter for injunction actions, and the agency and the courts developed logical policy reasons for such a distinction. ${ }^{53}$ In 1975, Congress revised the securities laws and added a provision preventing consolidation of public and private anti-fraud actions, apparently because of the potentially different scienter requirements. Hearings in 1977 focused on the scienter issue and expressed general legislative approval of the position taken by the SEC and the lower courts. ${ }^{54}$ The Court's only response to these arguments, contained in a footnote, was that "since the legislative consideration of those statutes was addressed principally to matters other than that at issue here, it is our view that the failure of Congress to overturn the Commission's interpretation falls far short of providing a basis to support a construction of $\S 10(\mathrm{~b})$ so clearly at odds with its plain meaning and legislative history." 55

To apply the precepts of these acquiescence cases to Patterson, consider the following chronology. In 1968, the Supreme Court held in Jones v. Alfred H. Mayer Co. ${ }^{56}$ that section 1982 's $\mathrm{s}^{57}$ prohibition of discrimination in the sale or rental of property applies to private as well as public conduct. Since section 1982 is also (apparently) taken from section 1 of the 1866 Civil Rights Act, lower courts between 1968 and 1972 all but unanimously interpreted section 1981 to apply to discrimination in private contract matters. ${ }^{58}$ Congress was well aware of this stream of lower court decisions, for when it was considering the 1972 amendments to Title VII of the Civil Rights Act, it rejected efforts to make Title VII the exclusive remedy for employment discrimination. ${ }^{59}$ Then, in three decisions between 1972 and 1976, the Supreme Court explicitly held that section 1981 applies to private contracts. ${ }^{60}$ Soon after the Court's decision in Runyon, Congress enacted the Fees Act of

53. See Aaron, 446 U.S. at $715-16$ \& n.6 (Blackmun, J., dissenting).

54. See 446 U.S. at 717 n.9.

55. 446 U.S. at 694 n.11 (majority opinion).

56. 392 U.S. 409 (1968).

57. 42 U.S.C. $\S 1982$ (1982).

58. See C. Abernathy, Civil Rights: CASES AND MATERials 265-76 (1980); Petitioner's Brief, supra note 8, app. B (collecting the lower court cases). The only reported exception was Cook v. Advertiser Co., 323 F. Supp. 1212 (M.D. Ala. 1971), affd. on other grounds, 458 F.2d 1119 (5th Cir. 1972).

59. See Part I.C infra.

60. Runyon v. McCrary, 427 U.S. 160, 168-75 (1976); Johnson v. Railway Express Agency, Inc., 421 U.S. 454, 459-60 (1975); Tillman v. Wheaton-Haven Recreation Assn., Inc., 410 U.S. $431,439-40$ (1973). 
$1976,{ }^{61}$ which assumed the correctness of Runyon's interpretation and sought to encourage section 1981 and 1982 lawsuits by providing counsel fees to prevailing parties. ${ }^{62}$ Since 1976, the Supreme Court has repeatedly held or assumed that sections 1981 and 1982 apply to private discrimination. ${ }^{63}$ Congress has done nothing to alter or overturn that interpretation, even though it has overturned other Supreme Court interpretations of civil rights statutes in the last ten years. ${ }^{64}$

This chronology seems to make Patterson very much like Apex Hosiery: "[T]he matter has been fully brought to the attention of the public and the Congress," and "the latter has not seen fit to change the statute."65 And like Flood: By its "positive inaction"66 in rejecting the proposals to limit section 1981, Congress has accepted the judicial interpretation of the statute. And like Bob Jones: "Congress affirmatively manifested its acquiescence," 67 not only by rejecting proposals to overturn the interpretation, but by building on the interpretation in the Fees Act. For substantially the same reasons, Patterson does not seem to fall under any of the three exceptions to the acquiescence rule. ${ }^{68}$

\section{B. The Reenactment Cases}

In many of the acquiescence cases, including Apex Hosiery, the Court has emphasized that Congress' inaction was meaningful because Congress had focused on the statute and actually amended it. Even though the amendments did not add or detract from the prior interpretation at issue, Congress' failure to respond to that interpretation

61. Runyon was decided on June 25,1976 . The Senate and House Judiciary Committees issued their reports in the summer, both mentioning the Supreme Court cases holding $\S 1981$ applicable to private contracts. The Senate passed the bill on September 29, and the House on October 1.

62. See Part I.B infra.

63. See Saint Francis College v. Al-Khazraji, 107 S. Ct. 2022, 2026-28 (1987) (person of Arabian descent may sue under $\$ 1981$, relying on $R$ unyon and legislative debates for 1866 Civil Rights Act); Shaare Tefila Congregation v. Cobb, 107 S. Ct. 2019, 2021 (1987) (Jews are a group protected by $\S 1982$, reaffirming Alfred $H$. Mayer); McDonald v. Santa Fe Trail Transp. Co., 427 U.S. 273 (1976) (Caucasians may sue under $\$ 1981$ ).

64. See Civil Rights Restoration Act of 1988, Pub. L. No. 100-259, 102 Stat. 28 (1988) (overturning Grove City College v. Bell, 465 U.S. 555 (1984)); Pregnancy Discrimination Act of 1978, 42 U.S.C. $\$ 2000 \mathrm{e}(\mathrm{k})$ (1982)(overturning General Elec. Co. v. Gilbert, 429 U.S. 125 (1976)).

65. Apex Hosiery, 310 U.S. at 489.

66. Flood, 407 U.S. at 283.

67. Bob Jones, 461 U.S. at 574.

68. The most pertinent exception would be the Aaron exception for clearly erroneous interpretations. Professor Farber makes a good case for Runyon's interpretation in Statutory Interpretation, Legislative Inaction, and Civil Rights, 87 MICH. L. REv. 3, 6-7 (1988). See also note 173 infra. 
when it was considering the precise statute "is itself evidence that Congress affirmatively intended to preserve [the interpretation]."69 This form of the acquiescence argument is closely related to the reenactment rule, which the Court generally treats as a separate doctrine. There have been a number of cases throughout the century in which the Court has held that "the reenactment by Congress, without change, of a statute which had previously received long continued executive [or judicial] construction, is an adoption by Congress of such construction."70 The leading recent articulation of the rule is the Court's statement in Lorillard v. Pons: ${ }^{71}$ "Congress is presumed to be aware of an administrative or judicial interpretation of a statute and to adopt that interpretation when it re-enacts a statute without change."72

Although the Lorillard principle shows up in many Supreme Court opinions and seems more procedurally attractive than the bare acquiescence rule, it too is rather cautiously invoked by the Court. The rule is rarely the primary basis for the Court's decision, and when it is the primary basis, the Court often seeks to reassure itself that Congress actually was (or must have been) aware of the existing interpretations when it reenacted the provision in question. An illustrative case is United States v. Board of Commissioners of Sheffield, Alabama. ${ }^{73}$ Section 5 of the Voting Rights Act of 1965 provides for Department of Justice preclearance of specified electoral changes for "a State or political subdivision" covered by section 4 of the Act. In Sheffield, the Court held that municipalities within covered states are subject to

69. Merrill Lynch, Pierce, Fenner \& Smith, Inc. v. Curran, 456 U.S. 353, 381-82 (1982); see Commodity Futures Trading Commn. v. Schor, 478 U.S. 833 (1986); Lindahl v. Office of Personnel Mgt., 470 U.S. 768, 782-83 \& n.15 (1985); North Haven Bd. of Educ. v. Bell, 456 U.S. 512 (1982).

70. United States v. Cerecedo Hermanos y Compañia, 209 U.S. 337, 339 (1908). See also United States v. G. Falk \& Brother, 204 U.S. 143, 152 (1907). The Court applied this reenactment rule to judicial decisions in Hecht v. Malley, 265 U.S. 144, 153 (1923); National Lead Co. v. United States, 252 U.S. 140, 146-47 (1920).

71. 434 U.S 575 (1978).

72. 434 U.S. at 580 (citations omitted). The issue in Lorillard was whether Congress meant to "borrow" accepted judicial interpretations of one statute when it borrowed language from that statute. See also Director, OWCP v. Perini N. River Assocs., 459 U.S. 297, 319-20 (1983). The Court considers Lorillard equally applicable to situations where the reenactment of the same statute adopts prior interpretations of that statute. Pierce v. Underwood, $108 \mathrm{~S}$. Ct. 2541, 2551 (1988). For older examples, see United States v. Ryan, 284 U.S. 167, 175 (1931); Hecht v. Malley, 265 U.S. 144 (1924); Latimer v. United States, 223 U.S. 501 (1912). Older leading cases for the reenactment rule are Helvering v. Wilshire Oil Co., 308 U.S. 90, 100-01 (1939); Helvering v. Bliss, 293 U.S. 144, 151 (1934); Johnson v. Manhattan Ry. Co., 289 U.S. 479, 500 (1933); McCaughn v. Hershey Chocolate Co., 283 U.S. 488, $492-93$ (1931); Heald v. District of Columbia, 254 U.S. 20, 22-23 (1920); United States v. Cerecedo Hermanos y Compañia, 209 U.S. 337 (1908).

73. 435 U.S. 110 (1978). 
preclearance review. The Court's main argument was that the Attorney General, charged with enforcing the statute, had long interpreted preclearance to apply to municipalities and school districts and that Congress had reenacted the Act in 1970 and 1975, without changing section 5 to overrule that interpretation. "When a Congress that reenacts a statute voices its approval of an administrative or other interpretation thereof, Congress is treated as having adopted that interpretation, and this Court is bound thereby." 74 The Court was sensitive to the argument that "it is impermissible to draw inferences of approval from the unexplained inaction of Congress," 75 but responded that Congress was fully aware of the Attorney General's interpretation and approved of it. For example, in 1975 an Assistant Attorney General testified explicitly about his Department's policy in House and Senate hearings, and several other witnesses directly or indirectly assumed that the Department's policy was settled. ${ }^{76}$ Not only was this view reflected in comments even of opponents to the 1975 extension, but also the House and Senate committee reports explicitly contemplated that the preclearance requirement would apply to municipalities and school districts. ${ }^{77}$

As it did in Sheffield, the Court may elevate executive department interpretations of statutes into settled meaning if Congress has not only reenacted the statute, but also was aware of the executive interpretation and seemed not unhappy with the interpretation. ${ }^{78}$ The same principle applies to interpretations by independent agencies. "When the statute giving rise to the longstanding interpretation has been re-enacted without pertinent change, the 'congressional failure to revise or repeal the agency's interpretation is persuasive evidence that the interpretation is the one intended by Congress." "79 And, as in Lorillard itself, the Court will find that Congress' reenactment of a statute will incorporate settled judicial interpretations of the statute. ${ }^{80}$

74. 435 U.S. at 134.

75. 435 U.S. at 135.

76. 435 U.S. at 133.

77. 435 U.S. at 134.

78. Recent cases elevating executive department interpretations include Wright v. City of Roanoke Redev. \& Hous. Auth., 107 S. Ct. 766, 774 (1987); City of Pleasant Grove v. United States, 107 S. Ct. 794, 798 (1987); Commissioner v. Engle, 464 U.S. 206, 224-25 (1984); Haig v. Agee, 453 U.S. 280, 297-301 (1981); Board of Educ. v. Harris, 444 U.S. 130, 148-49 (1979); Zenith Radio Corp. v. United States, 437 U.S. 443, 457 (1978); Don E. Williams Co. v. Commissioner, 429 U.S. 569, 575-77 (1977); FERC v. Algonquin SNG, Inc., 426 U.S. 548, 567-71 (1976).

79. FDIC v. Philadelphia Gear Corp., 476 U.S. 426, 437 (1986) (quoting NLRB v. Bell Aerospace Co., 416 U.S. 267, 275 (1974) (leading case)); see also Commodity Futures Trading Commn. v. Schor, 478 U.S. 833 (1986); Chemehuevi Tribe v. FPC, 420 U.S. 395, 410 (1975).

80. See, e.g., Pierce v. Underwood, 108 S. Ct. 2541, 2550-51 (1988); Kelly v. Robinson, 479 U.S. 36 (1986); Midlantic Natl. Bank v. New Jersey Dept. Env. Protection, 474 U.S. 494, 501 
While the Court in these cases often invokes the reenactment rule without a specific showing that Congress was aware of the judicial interpretations, the Court usually makes an effort to demonstrate that Congress "must" have been aware of the interpretations.

In Snyder v. Harris, ${ }^{81}$ the issue was whether separate claims presented by various claimants in a class action could be aggregated to provide the $\$ 10,000$ amount in controversy required under the diversity jurisdiction statute. ${ }^{82}$ A long line of Supreme Court decisions had interpreted the statute not to allow aggregation, but the class argued that the approach taken by these decisions was impractical and unnecessarily grudging, especially in light of new developments in class actions. The Court rejected this argument, based upon a cautious invocation of the reenactment rule. "There are no doubt hazards and pitfalls involved in assuming that re-enactment of certain language by Congress always freezes the existing judicial interpretation of statutes involved," but the Court was persuaded that the reenactment rule was applicable, because it believed the "settled judicial interpretation of 'amount in controversy' was implicitly taken into account" by Congress. ${ }^{83}$ Congress had deliberated about the amount in controversy and raised the amount three times in the last century, ${ }^{84}$ each time reenacting the diversity statute otherwise intact. Surely, the Court supposed, Congress must have given thought to the established nonaggregation rule. ${ }^{85}$

Like the acquiescence rule, the reenactment rule is not always followed, and the three strategies for avoiding the acquiescence rule are also used to avoid the reenactment rule. The leading case is Girouard v. United States. ${ }^{86}$ Girouard held that the Nationality Act of 1940 did not require an alien to take an oath to bear arms for this country in order to obtain citizenship. A dissenting opinion by Chief Justice Harlan Stone, the author of Apex Hosiery, relied on prior Supreme

(1986); Bloomer v. Liberty Mut. Ins. Co., 445 U.S. 74, 85 (1980); Owen Equip. \& Erection Co. v. Kroger, 437 U.S. 365, 374 n.16 (1978); Douglas v. Seacoast Prods., Inc., 431 U.S. 265, 278-79 (1977); United States v. American Bldg. Maintenance Indus., 422 U.S. 271, 279-81 (1975); A1bemarle Paper Co. v. Moody, 422 U.S. 405, 414 n.8 (1975); Deepsouth Packing Co. v. Laitram Corp., 406 U.S. 518, 530 (1972).

81. 394 U.S. 332 (1969).

82. 28 U.S.C. $\S 1332$ (1982).

83. 394 U.S. at 339.

84. The Act of March 3, 1887, 24 Stat. 552, raised the amount from $\$ 500$ to $\$ 2000$. The Act of March 3, 1911, $\$ 24,36$ Stat. 1091, raised the amount to $\$ 3000$. The Act of July $25,1958,72$ Stat. 415 , raised the amount to $\$ 10,000$.

85. 394 U.S. at $339-40$.

86. 328 U.S. 61 (1946). Girouard relied upon Helvering v. Hallock, 309 U.S. 106 (1940) Although the Court treated the case mainly as an acquiescence case, Hallock is, technically, also a reenactment case. See Hallock, 309 U.S. at 120 n.7. 
Court interpretations of the statutory oath requirement. Although the Chief Justice had not joined the earlier precedents, he felt bound by them, since Congress had "adopted" them; not only had Congress failed to amend the Nationality Act in response to public efforts to overrule the decisions, it had, instead, reenacted the provision without change in 1940.87 The Court rejected the reenactment argument, using language identical to that of Hallock. " 'It would require very persuasive circumstances enveloping Congressional silence to debar this Court from reexamining its own doctrines," the Court reasoned. "It is at best treacherous to find in congressional silence alone the adoption of a controlling rule of law."B8 More persuasive for the Court than Congress' inaction in 1940 was Congress' action in 1942, when Congress specifically amended the Nationality Act to permit noncombatants to become citizens. The Court concluded that "the affirmative action taken by Congress in 1942 negatives any inference that otherwise might be drawn from its silence when it reenacted the [statute] in 1940."89

Girouard represents one strategy for avoiding the reenactment rule; as in Monell, Congress acted as though the prior judicial interpretation was not settled law. Two other strategies for avoiding the reenactment rule are illustrated by the Court's decision in Leary $v$. United States. ${ }^{90}$ The Court invalidated the transfer tax provision of the Marihuana Tax Act ${ }^{91}$ on the ground that they required defendant, Dr. Timothy Leary, to supply the government with self-incriminating information. The government sought to sidestep this constitutional difficulty by claiming that the registration requirements of the statute were only applicable to persons engaged in legal use of marihuana; it relied upon administrative regulations to this effect, and implicit legislative approval of those regulations when Congress reenacted the statute in 1954. The Court rejected this use of the reenactment rule, primarily because the Court found it patently unsupported by the statutory language and the legislative history. Although "congressional re-enactment of a statute, even without any apparent knowledge of a particular regulation, can 'strengthen to some extent' the regulation's claim to validity ... re-enactment cannot save a regulation which 'contradict[s] the requirements' of the statute itself." 92 This represents

87. 328 U.S. at 73-76 (Stone, C.J., dissenting).

88. 328 U.S. at 69 (quoting Hallock, 309 U.S. at 119).

89. 328 U.S. at 70.

90. 395 U.S. 6 (1969).

91. 26 U.S.C. $\S \S 4741-4746$ (repealed 1970).

92. 395 U.S. at 24-25 (quoting Massachusetts Trustees of Eastern Gas \& Fuel Assoc. v. United States, 377 U.S. 235, 241, 242 (1964)). 
a second strategy around the reenactment rule: Where the prior interpretation is flatly inconsistent with relatively clear statutory language or history, the Court may abandon the Lorillard presumption that Congress was aware of and adopted the prior line of interpretation.

Leary also rejected the reenactment rule because the Court was doubtful that the government's interpretation was in fact the "longstanding interpretation" of the Act by the agencies charged with enforcing it. ${ }^{93}$ This represents the third strategy for getting around the reenactment rule: Congress cannot be presumed to "know" an administrative interpretation that is unsettled even in the minds of the administrators. Rodriguez v. Compass Shipping Co. ${ }^{94}$ illustrates this exception in connection with prior judicial interpretations. A unanimous Court held that Congress' thorough overhaul of the Longshoremen and Harborworkers Compensation Act in 1972 did not implicitly codify a decision of the District of Columbia Circuit Court of Appeals which permitted longshoremen to sue third parties, and not just their immediate employers, once it became clear the employers would not sue the third parties. ${ }^{95}$ The Court found that the earlier interpretation was inconsistent with both the language and purpose of the 1972 statute and that the single lower court decision was not the "well-established" interpretation that Congress should be presumed to know. ${ }^{96}$ Probably for this reason, the Court often will not incorporate lower court decisions into a statute through the reenactment rule. ${ }^{97}$

Under these reenactment cases, the Fees Act of 1976 significantly buttresses the acquiescence argument in Patterson. The statute itself provides counsel fees for prevailing plaintiffs in cases brought under sections 1981, 1982, and 1983 of title 42.98 Section 1983 provides a remedy for persons discriminated against by state actors, and sections 1981 and 1982 - as interpreted in Runyon and Alfred H. Mayer provide a substantially parallel remedy for persons discriminated

93. 395 U.S. at 25.

94. 451 U.S. 596 (1981).

95. Potomac Elec. Power Co. v. Wynn, 343 F.2d 295 (D.C. Cir. 1965) (per curiam).

96. 451 U.S. at 614-16. Cf. Edmonds v. Compagnie Generale Transatlantique, 443 U.S. 256 (1979) (ruling that the codification of a judicially created rule should be interpreted consistently with that rule).

97. For decisions refusing to apply the reenactment rule to a series of lower court decisions, see Dickman v. Commissioner, 465 U.S. 330, 346-48 (1984); Mohasco Corp. v. Silver, 447 U.S. 807 (1980); Aaron v. SEC, 446 U.S. 680, 692-94 (1980); United States v. Powell, 379 U.S. 48, 55 n.13 (1964).

98. 42 U.S.C. $\S 1988$ (1982): "In any action or proceeding to enforce a provision of sections 1981, 1982, 1983, 1985, and 1986 of this title, title IX of Public Law 92-318, or title VI of the Civil Rights Act of 1964 , the court, in its discretion, may allow the prevailing party, other than the United States, a reasonable attorney's fee as part of the costs." 
against by private actors. Overruling Runyon would render section 1981 largely repetitious of section $1983,{ }^{99}$ a result at odds with the text of section 1988. Indeed, the Senate report suggested that the main reason sections 1981 and 1982 were included was to assure that plaintiffs pursuing lawsuits against private discrimination would have counsel fee incentives similar to those of plaintiffs suing under Titles VII and VIII of modern civil rights laws. ${ }^{100}$ The House report and floor statements by Representative Drinan (the House manager of the bill) and Senator Tunney (the Senate manager) also expressed congressional understanding and approval of the Supreme Court's interpretation of section 1981.101

This brief history of the Fees Act suggests that the reenactment cases support the legislative inaction argument in Patterson. The Lorillard precept that "Congress is presumed to be aware of [a] judicial interpretation of a statute and to adopt that interpretation when it re-enacts a statute without change"102 seems applicable, even though the Fees Act only referred to section 1981 and did not reenact it. As in Sheffield, committee reports and floor debate amplify the inference that Congress understood the implications of Runyon and incorporated its holding in section 1988. As in Snyder, a "settled judicial in terpretation . . . was . . taken into account" by Congress when it passed the law. ${ }^{103}$

\section{The Rejected Proposal Cases}

In many of its acquiescence and reenactment cases, the Court fortifies its argument that legislative inaction has ratified the existing interpretation by pointing to the rejection of the opposite interpretation by

99. Such a ruling would not render the section entirely redundant. For example, $\S 1981$ has been interpreted to cover federal contractual matters, e.g., Bowers v. Campbell, 505 F.2d 1155 (9th Cir. 1974), that are not covered by Title VII.

100. S. REP. No. 1011, 94th Cong., 2d Sess. 4, reprinted in 1976 U.S. CODE CONG. \& ADMIN. NEwS 5908, 5911: "[F]ees are now authorized in an employment discrimination suit under Title VII of the 1964 Civil Rights Act, but not in the same suit brought under 42 U.S.C. $\$ 1981$, which protects similar rights but involves fewer technical prerequisites to the filing of an action. Fees are allowed in a housing discrimination suit brought under Title VIII of the Civil Rights Act of 1968, but not in the same suit brought under 42 U.S.C. $\S 1982$, a Reconstruction Act protecting the same rights."

101. H.R. REP. No. 1558, 94th Cong., 2d Sess. 4 \& n.8 (1976) (citing with approval two Supreme Court cases holding $\S 1981$ applicable to private discrimination and noting with ap. proval a House committee's view that $\$ 1981$ and Title VII remedies are "co-extensive"); 122 CONG. REC. 35122 (1976) (Rep. Drinan) ( $\$ 1981$ \& 1982 "generally prohibit the denial of civil and constitutional rights in a variety of areas"; Fees Act not meant to disturb this); 121 CoNG. REC. S 14975 (daily ed. Aug. 1, 1975) (Sen. Tunney) (§ 1981 protects "similar rights" as Title VII and ought to have similar counsel fee provision).

102. Lorillard, 434 U.S. at 580.

103. Snyder, 394 U.S. at 339. 
either the enacting Congress or a subsequent one. For example, the "positive inaction" upon which Flood relied was, in part, Congress' consideration of dozens of proposed bills seeking to modify the rule of Federal Baseball and its refusal to enact any of them. The rejected proposal rule is not limited to these cases, however, and has evolved into an independent doctrine, with its own line of important Supreme Court cases. "Few principles of statutory construction are more compelling than the proposition that Congress does not intend sub silentio to enact statutory language that it has earlier discarded in favor of other language." "104 Where a committee, or one chamber of Congress, or a conference committee has voted against including specific language in a statute or an amendment to a statute, the Court will often refuse to read that interpretation into the statute.

A leading case is Albemarle Paper Co. v. Moody. ${ }^{105}$ One issue in the case was whether backpay could be awarded to those unnamed members of a Title VII class action who had not themselves filed charges with the Equal Employment Opportunity Commission (EEOC). The Court held that such relief could be awarded in a class action, even though EEOC charges are normally a prerequisite to obtaining such relief in ordinary lawsuits. The Court noted that all the circuit courts addressing the issue had so held, and concluded that the Congress "ratified" those cases when it amended Title VII in 1972. ${ }^{106}$ The House version of the 1972 amendment would have barred backpay to class members who had not filed charges. The Senate passed a bill without the House provision, based upon its committee recommendation, which in turn relied on and cited the circuit court opinions. The conference committee adopted the Senate version and specifically rejected the House provision. From this evidence, the Court concluded that the backpay issue was settled. ${ }^{107}$

As in most of the rejected proposal cases, the rejection in Albemarle Paper was made by a subsequent Congress, not the one actually passing the statute being interpreted. An example of a contem-

104. INS v. Cardoza-Fonseca, 107 S. Ct. 1207, 1219 (1987) (quoting Nachman Corp. v. Pension Benefit Guar. Corp., 446 U.S. 359, 392-93 (1980) (Stewart, J., dissenting)). Other recent rejected proposal cases include Tanner v. United States, 107 S. Ct. 2739, 2748-50 (1987); Burlington N. R.R. v. Brotherhood of Maintenance of Way Employees, 107 S. Ct. 1841, 1848 (1987); United States v. Johnson, 107 S. Ct. 2063, 2066 \& n.6 (1987); Local 28, Sheet Metal Workers' Intl. Assn. v. EEOC, 106 S. Ct. 3019, $3045-47$ (1986) (plurality opinion); Dames \& Moore v. Regan, 453 U.S. 654, 685-86 (1981).

105. 422 U.S. 405 (1975).

106. The Equal Employment Opportunity Act of 1972, Pub. L. No. 92-261, 86 Stat. 103.

107. 422 U.S at 414 n.8. 
poraneous rejection is found in Sinclair Refining Co. v. Atkinson. ${ }^{108}$ The Court held that, in a lawsuit brought under section 301 of the Labor Management Relations Act of 1947 (LMRA) "for violation of contracts between an employer and a labor organization,"109 an employer could not obtain an injunction against a strike called in violation of a labor-management agreement, because the Norris-LaGuardia Act bars federal courts from issuing injunctions "in any case involving or growing out of any labor dispute."110 The Court relied in part upon a rejected proposal argument. The conference committee for the 1947 Act rejected a provision in the House bill that would have made the Norris-LaGuardia Act inapplicable to suits brought to enforce section 301 duties." "When the repeal of a highly significant law is urged upon [Congress] and that repeal is rejected after careful consideration and discussion, the normal expectation is that courts will be faithful to their trust and abide by that decision."112

Albemarle Paper and Sinclair illustrate the Court's willingness to find significance in a conference committee's rejection of a specific provision; such rejection "strongly militates against a judgment that Congress intended a result that it expressly declined to enact."113 The Court may also infer meaning from the rejection of a specific proposal or interpretation by one chamber of Congress: "There could hardly be a clearer indication of congressional agreement" with one interpretation than one chamber's rejection of a proposal to change the settled interpretation. ${ }^{114}$ In North Haven Board of Education v. Bell, ${ }^{115}$ for example, the Court interpreted Title IX of the Education Amendments of $1972,{ }^{116}$ which prohibits sex discrimination in federally funded or assisted programs, to include employment discrimination. The Court relied upon the broad statutory language and a summary of the bill by its Senate sponsor as the primary bases for its interpretation, but it also relied upon the Title IX regulations developed by the

108. 370 U.S. 195 (1962) (overruled by Boys Markets, Inc. v. Retail Clerks Union, Local 770, 398 U.S. 235 (1970)).

109. 61 Stat. 156 (codified at 29 U.S.C. § 185(a) (1982)).

110. Pub. L. No. $72-65, \S 4,47$ Stat. 70 (1932) (codified as amended at 29 U.S.C. $\S 104$ (1982)).

111. H.R. CONF. REP. No. 510, 80th Cong., 1st Sess. 66 (1947); see Sinclair, 370 U.S. at 20509.

112. 370 U.S. at 210.

113. Gulf Oil Corp. v. Copp Paving Co., 419 U.S. 186, 200 (1974) (conference committee deleting House language); see cases cited in Appendix 3(A) infra.

114. Runyon, 427 U.S. at 174-75; see cases cited at Appendix 3(B) infra.

115. 456 U.S. 512 (1982).

116. Pub. L. No. $92-318,86$ Stat. 373 (codified as amended at 20 U.S.C. $\$ \S 1681-1686$ (1982)). 
Department of Health, Education and Welfare, which is charged with implementing Title IX. When the regulations were submitted to Congress for formal examination in 1975, several resolutions were introduced to disapprove the regulations, including one resolution specifically objecting to the regulations dealing with employment discrimination. Congress voted down the resolutions, and the Court found the rejection significant evidence that Congress believed Title IX includes employment discrimination. ${ }^{117}$ In North Haven Board of Education, the rejected proposal rule reinforced the acquiescence rule, but in other cases the Court has found significance in one chamber's rejection of amendments or proposed language, even when there has been no judicial or agency interpretation in the background. ${ }^{118}$

Finally, the Court will sometimes rely upon the rejection of proposed legislation by congressional committees. ${ }^{119}$ The leading case is Blue Chip Stamps v. Manor Drug Stores. ${ }^{120}$ The Court held that private parties may not sue those making a stock offering for fraud under the securities laws when the claimants have neither purchased nor sold any of the offered shares. The primary argument made by the Court rested upon the acquiescence rule and the rejected proposal rule.121 The Second Circuit in Birnbaum v. Newport Steel Corporation ${ }^{122}$ had so held in 1952, and courts and commentators for two decades accepted this ruling as the settled interpretation.123 More significantly, the SEC apparently realized that, and in 1957 and 1959 petitioned Congress to amend the statute to broaden standing to raise anti-fraud issues. ${ }^{124}$ The Senate Committee on Banking held hearings on the proposals, which were controversial because they would expand liability under the anti-fraud provisions. The committee did not recommend the SEC's bills, and they died. "The longstanding acceptance by the courts, coupled with Congress' failure to reject Birnbaum's reasonable interpretation ... argues significantly in fayor of acceptance of the Birnbaum rule by this Court." 125

In most of the cases where the Court has refused to draw significance from a rejected proposal, it has stressed that the proposal dif-

117. 456 U.S. at 531-35.

118. See, e.g., Burlington N. R.R. v. Brotherhood of Maintenance of Way Employees, 107 S. Ct. 1841, 1848 (1987); Bradley v. School Bd., 416 U.S. 696, 716 n.23 (1974).

119. See cases cited in Appendix 3(C) infra.

120. 421 U.S. 723 (1975).

121. 421 U.S. at $732-33$.

122. 193 F.2d 461 (2d Cir.), cert. denied, 343 U.S. 956 (1952).

123. 421 U.S. at 731-32.

124. 421 U.S. at 732.

125. 421 U.S. at 733. 
fered from the interpretative issue then under consideration, and Congress therefore was not faced with a clear referendum on that issue. For example, Monell overruled Monroe v. Pape, ${ }^{126}$ which had interpreted section 1983 not to apply to municipalities. Monroe's main argument was that the Congress enacting the Civil Rights Act of 1871 rejected an amendment that would have subjected municipalities to liability for damage done by private persons "riotously and tumultuously assembled." Monell demonstrated the irrelevance of that inaction by arguing that the amendment was rejected, not because it imposed liability on municipalities, but because it held them responsible for the acts of private citizens and, hence, carried respondeat superior too far. ${ }^{127}$

Another case refusing to rely upon rejected proposals is $N L R B v$. Catholic Bishop of Chicago. ${ }^{128}$ The Court held that the National Labor Relations Act (NLRA) does not give the National Labor Relations Board (NLRB) jurisdiction over educational institutions that are associated with a religious denomination and teach secular as well as religious subjects. The dissenting opinion relied upon two rejected proposal arguments. First, when the NLRA was amended by the LMRA in 1947, the conference committee rejected a House provision that would have precluded NLRB jurisdiction over religiously associated educational institutions. ${ }^{129}$ Second, when the NLRA was amended in 1974 to repeal the exclusion of nonprofit hospitals, the Senate rejected an amendment to exempt hospitals operated by religious groups, arguing that " "national [labor] policy ... holds religiously affiliated institutions ... to the same standards as their nonsectarian counterparts." "130 The Court found that these rejected proposals did not reflect any "affirmative intention" of Congress on this issue because the Board did not assert jurisdiction over churchoperated schools until after 1974.131 Hence, there was not a tangible policy tradition to which Congress could respond.

The legislative inaction argument in Patterson finds substantial support in these rejected proposal cases. Proposals to exclude section 1981 from employment discrimination litigation were rejected by Congress when it amended Title VII of the Equal Employment Opportu-

126. 365 U.S. 167 (1961).

127. Monell, 436 U.S. at 690-95.

128. 440 U.S. 490 (1979).

129. See 440 U.S. at 513-14 (Brennan, J., dissenting).

130. 440 U.S. at 515 (emphasis omitted) (quoting 120 CoNG. Rec. 12957 (1974) (Sen. Cranston, floor manager of Senate bill)).

131. 440 U.S. at 505-06. I confess that this is a pretty lame response by the Court, and I find Catholic Bishop a particularly weak case. 
nity Act of 1972.132 Referring explicitly to the Civil Rights Act of 1866 (hence implicitly to section 1981), Senator Hruska introduced an amendment to the Senate bill to make Title VII and the Equal Pay Act the exclusive remedies for employment discrimination. ${ }^{133}$ Senator Williams, the floor manager for the bill, vociferously opposed the Hruska amendment, emphasizing the importance of section 1981 as an "alternative means to redress individual grievances" 134 and vowed that he would give up the whole bill before allowing the repeal of section 1981. ${ }^{135}$ The Senate twice rejected Senator Hruska's amendment. 136 The House bill, however, included a provision making Title VII the exclusive remedy. ${ }^{137}$ In conference committee, the House receded from its position, and the final version of the statute had no exclusive remedy provision. ${ }^{138}$

The proposal's rejection in 1972 arguably brings Patterson within the Supreme Court's precedents. The case seems similar to Albemarle Paper and Sinclair: The rejection of the House repeal of section 1981 (for employment cases) in the conference committee "strongly militates against a judgment that Congress intended a result that it expressly declined to enact." 139 And like North Haven Board of Education: The rejection of Senator Hruska's proposal supports the inference that Congress was aware of, deliberated about, and accepted the prevailing judicial interpretation of section 1981 as applicable to private discrimination:

132. Pub. L. No. $92-261,86$ Stat. 103 (codified as amended at 42 U.S.C. $\$ \S 2000 \mathrm{e}-1$ to -17 (1982)).

133. 118 CONG. REC. 3172-73 (1972) (Sen. Hruska).

134. Id. at 3371 (Sen. Williams).

The right of individuals to bring suits in Federal courts to redress individual acts of discrimination ... was first provided by the Civil Rights Acts of 1866 and 1871, 42 U.S.C. sections 1981,1983 . It was recently stated by the Supreme Court in the case of Jones v. Mayer, that these acts provide fundamental constitutional guarantees. In any case, the courts have specifically held that Title VII and the Civil Rights Acts of 1866 and 1871 are not mutually exclusive, and must be read together to provide alternative means to redress individual grievances.

Mr. President, the amendment of [Senator Hruska] will repeal the first major piece of civil rights legislation in this Nation's history. We cannot do that.

Id. (Sen. Williams).

135. Id. at 3963.

136. Id. at 3373, 3965; see also Runyon, 427 at $174 \mathrm{n} .11$ (discussion of Hruska amendment).

137. See 117 CoNG. REC. 31973 (1971) (Rep. Erlenborn) (under substitute bill "[t]here would no longer be recourse to the old 1866 civil rights act"); id. at 32111 (House vote 200-195 to adopt Erlenborn substitute).

138. H.R. CONF. REP. No. 899, 92d Cong., 2d Sess. 17 (1972).

139. Gulf Oil Corp. v. Copp Paving Co., 419 U.S. 186, 200 (1974). 


\section{Problems With INFERring Legislative Intent From LEGISLATIVE INACTION}

Based upon the analysis in Part I, one might conclude that the Supreme Court's legislative inaction decisions are coherent and make a fair amount of sense out of delphic signals from the legislature. These conclusions would be hasty. I have made the best effort I can to present the range of outcomes and the Court's reasoning as coherently as possible. Thus, Part I emphasized, as the Court does, the legal process context of the legislative inaction in each case: Was Congress aware of the interpretation, and did it deliberate about it? ${ }^{140}$ If so, its failure to act has interpretive significance, as the Court seems to be saying in cases like Apex Hosiery, Flood, Snyder, and Sinclair. "There could hardly be a clearer indication of congressional agreement" with a particular interpretation, than Congress' focusing on it and failing to change it, the Court said in Runyon ${ }^{141}$ and might say again in Patterson.

Yet the cases are not as coherent as my summary in Part I might suggest. Upon close examination, some of the cases might be considered internally incoherent. For example, Bob Jones' invocation of congressional acquiescence in the 1970 IRS interpretation of section 501(c)(3) is inconsistent with Congress' similar acquiescence in exactly the opposite interpretation before $1970 .{ }^{142}$ Indeed, in the 1960s this issue was certainly a salient one, and at least one bill was introduced to overturn the prior IRS interpretation (it did not pass). ${ }^{143}$ Why should Congress' silence after 1970 count so much, while its silence before 1970 counts not at all? Bob Jones provides no explanation for this curiosity. A similar point can be made about Runyon. Its holding rested upon Congress' acquiescence in Alfred H. Mayer and lower court decisions extending that precedent to section 1981. Yet the Court ignored Congress' acquiescence in pre-Alfred $H$. Mayer decisions that had required a showing of state action for lawsuits under

140. Cf. 2A N. SINGER, supra note $10, \S 49.09$, at 400 (reenactment rule "is of special importance" where administrative or judicial interpretations are known to Congress and "does not apply where nothing indicates that the legislature had its attention directed to the administrative [or judicial] interpretation upon reenactment"); $i d . \$ 49.10$, at 408 (acquiescence is "of small consequence where the ... contemporaneous interpretation was not called to the legislature's attention" but is "presumptive evidence of its correctness" when the legislature was aware of it).

141. 427 U.S. at $174-75$.

142. See Freed \& Polsby, Race, Religion \& Public Policy: Bob Jones University v. United States, 1983 Sup. CT. REv. 1.

143. H.R. 6342, 89th Cong., 1st Sess., printed in 111 Cong. Rec. 5140 (1965) ("A bill to amend the Internal Revenue Code of 1954 to provide that an organization described in section 501(c)(3) of such code which engages in certain discriminatory practices shall be denied an exemption ...."); see Grabow, supra note 9, at 750-51. 
sections 1981 and 1982.144 Indeed, Congress' enactment of Title VII of the Civil Rights Act of 1964 apparently assumed that victims of racial discrimination by private sector employers had no federal remedy. Like Bob Jones, Runyon seems capricious in its invocation of legislative inaction.

Other cases are inconsistent with one another. Although Hallock is the leading anti-acquiescence case, the amount of active legislative deliberation over the interpretive question seems just as impressive as that in the leading acquiescence cases, such as Apex Hosiery. Thus, not only had Congress failed to overrule the Supreme Court's authoritative interpretation of section 302(c) of the Revenue Act of 1926, but Congress had reenacted it without change and had overruled judicial interpretations involving other section 302 issues. ${ }^{145}$ In short, there seems to be no procedural reason why the acquiescence arguments that prevailed in Apex Hosiery should not have prevailed in Hallock or Girouard. ${ }^{146}$ For an even more striking example, Sinclair is one of the most persuasive inaction cases, because the Congress enacting section 301 specifically rejected (at the conference committee) a proposal to allow injunctions to enforce section 301 and, pro tanto, to repeal the Norris-LaGuardia Act. Yet the Court eight years later, in Boys Markets, Inc. v. Retail Clerks Union, Local 770,147 overruled Sinclair. The overruling flies in the face not only of the rejected proposal rule but also of the acquiescence rule, since Sinclair was a well-publicized decision and proposals were advanced for Congress to overturn it, which never occurred. 148

There is, finally, incoherence at the level of rhetoric. For every case where the Court rhapsodizes about deliberative inaction, there is a counter-case subjecting such inferences to scathing critique. "To explain the cause of non-action by Congress when Congress itself sheds no light is to venture into speculative unrealities," the Court said in Hallock, where Congress not only had focused on the interpretive issue, but had changed the statute in other ways. ${ }^{149}$ "So what," the Court seemed to say. "Various considerations of parliamentary tactics

144. The dissenters in Jones v. Alfred H. Mayer Co., 392 U.S. 409 (1968), complained that its interpretation of $\S 1982$ overruled holdings of the Court in Hurd v. Hodge, 334 U.S. 24, 31 (1948), and Corrigan v. Buckley, 271 U.S. 323, 331 (1926). Alfred H. Mayer, 392 U.S. at 451-52 \& n.8 (Harlan, J., dissenting). But see 392 U.S. at 419 \& 420 n.25 (Court's response). Runyon's dissenters claimed that its interpretation of $\S 1981$ overruled dicta in the Civil Rights Cases. Runyon, 427 U.S. at 192 (White, J., dissenting).

145. Hallock, 309 U.S. 106, 129-32 (1940) (Roberts, J., dissenting).

146. Girouard, 328 U.S. 61, 73-76 (1946) (Stone, C.J., dissenting).

147. 398 U.S. 235 (1970).

148. See Boys Markets, 398 U.S. at 240; 398 U.S. at 258-59 (Black, J., dissenting).

149. 309 U.S. at 119-20. 
and strategy might be suggested as reasons for the inaction of the ... Congress, but they would only be sufficient to indicate that we walk on quicksand when we try to find in the absence of corrective legislation a controlling legal principle."150 Hallock is particularly eloquent, but similar invective can be found in many other opinions rejecting inaction arguments. ${ }^{151}$

The rhetorical debate has heated up in the last two years, in part because recently appointed Justice Scalia is forcefully critical of legislative inaction arguments, the acquiescence rule in particular. ${ }^{152}$ The debate on the Court is epitomized in Johnson v. Transportation Agency, Santa Clara County. ${ }^{153}$ In that case, the Supreme Court reaffirmed United Steelworkers $v$. Weber, ${ }^{154}$ which had interpreted Title VII to permit voluntary affirmative action in employment. Justice Scalia dissented in Johnson, arguing that the earlier interpretation was wrong and had malign policy consequences. ${ }^{155}$ The Court brushed aside this argument in a footnote, observing that "Congress has not amended the statute to reject our construction, nor have any such amendments even been proposed, and we therefore may assume that our interpretation was correct."156 Justice Scalia responded with various reasons why Congress' failure to amend the statute should have no significance, concluding that "vindication by congressional inaction is

150. 309 U.S. at 121.

151. My favorite invective is that in Zuber v. Allen, 396 U.S. 168, 185-86 n.21 (1969): "The verdict of quiescent years cannot be invoked to baptize a statutory gloss that is otherwise impermissible. ... Congressional inaction frequently betokens unawareness, preoccupation, or paralysis." See also Lukhard v. Reed, 107 S. Ct. 1807, 1814 (1987) ("It is of course not true that whenever Congress enacts legislation using a word that has a given administrative interpretation it means to freeze that administrative interpretation in place."); Sampson v. Murray, 415 U.S. 61, 78 (1974) ("This Court observed in [Scripps-Howard Radio v. FCC, 316 U.S. 4, 11 (1942)] that '[t]he search for significance in the silence of Congress is too often the pursuit of a mirage'. ..."); Red Lion Broadcasting Co. v. FCC, 395 U.S. 367, 382 n.11 (1969) ("In any event, unsuccessful attempts at legislation are not the best of guides to legislative intent."); United States $v$. Welden, 377 U.S. 95, 103 n.12 (1964) ("We do not expect Congress to make an affirmative move every time a lower court indulges in an erroneous interpretation." ") (quoting Jones v. Liberty Glass Co., 332 U.S. 524, 534 (1947)); United States v. Wise, 370 U.S. 405, 411 (1962) ("The interpretation placed upon an existing statute by a subsequent group of Congressmen who are promoting legislation and who are unsuccessful has no persuasive significance here."); Girouard, 328 U.S. at 69 ("It is at best treacherous to find in congressional silence alone the adoption of a controlling rule of law.").

152. For his criticisms of the acquiescence rule, see Lukhard v. Reed, 107 S. Ct. 1807, 1814 (1987); Johnson v. Transportation Agency, Santa Clara County, 107 S. Ct. 1442, 1472-73 (1987) (Scalia, J., dissenting); United States v. Johnson, 107 S. Ct. 2063, 2075 (1987) (Scalia, J., dissenting). He is willing to rely on the reenactment rule, though. Pierce v. Underwood, $108 \mathrm{~S}$. $\mathrm{Ct}$. 2541, 2550-51 (1988) (Scalia, J.).

153. 107 S. Ct. 1442 (1987).

154. 443 U.S. 193 (1979).

155. $107 \mathrm{~S}$. Ct. at 1465 (Scalia, J., dissenting).

156. $107 \mathrm{~S}$. Ct. at 1451 n.7. 
a canard."157 The Court replied that any interpretation of a statute invites legislative correction, that Congress has overruled other interpretations of Title VII, and that "on occasion an invitation declined is as significant as one accepted."158

The Johnson opinion encapsulated the prevailing rhetoric of the Court's legislative inaction cases with the following example: "When a court says to a legislature: "You (or your predecessor) meant $X$," it almost invites the legislature to answer: "We did not." "159 And when the legislature declines the invitation, one can infer that, more likely than not, it did mean " $X$." This reasoning suggests a highly persuasive metaphor for finding meaning in inaction: Wadlington tells Krattenmaker, "Go fetch me some soupmeat." Krattenmaker fetches beef, presents it to Wadlington with the query, "Isn't this the kind of meat you intended?" Wadlington says nothing. Under the acquiescence rule, we can infer that it is more likely than not that Wadlington did mean beef. Suppose Wadlington issues the same directive every week for a year, Krattenmaker brings beef every time, and Wadlington says nothing. Under the reenactment rule, we can infer that it is more likely than not that Wadlington did mean beef. Finally, suppose Wadlington's spouse suggests, "Dearest, why don't you have Krattenmaker fetch us some chicken instead of soupmeat?" And yet Wadlington immediately turns to Krattenmaker and asks only for "soupmeat." Under the rejected proposal rule, we can infer that it is more likely than not that Wadlington did mean beef. If one combines these three scenarios (as in Patterson), the inference is quite powerful. Wadlington meant beef.

When Johnson and other Supreme Court opinions make inferences from legislative inaction, they typically assert that these inferences tell us something probable about the actual "intention" of Congress as to the certain issue on which Congress has not responded.160 Congress is my hypothetical Wadlington. When viewed in this simple metaphori-

157. $107 \mathrm{~S}$. Ct. at 1473 (Scalia, J., dissenting).

158. $107 \mathrm{~S}$. Ct. at 1451 n.7.

159. $107 \mathrm{~S}$. Ct. at $1451 \mathrm{n} .7$ (quoting G. Calabresi, A Common Law for the AGe of STATUTES 31-32 (1982)).

160. In addition to Johnson, other legislative inaction decisions from the $1986 \mathrm{Term}$ deployed similar anthropomorphic terminology. See Agency Holding Corp. v. Malley-Duff \& Assocs., Inc., 107 S. Ct. 2759, 2762 (1987) (Because of "congressional awareness of this practice, we can generally assume that Congress intends by its silence that we borrow state law."); Tanner v. United States, 107 S. Ct. 2739, 2750 (1987) ("Congress specifically understood, considered, and rejected a version of Rule 606(b) that would have allowed jurors to testify on juror conduct."); INS v. Cardoza-Fonseca, 107 S. Ct. 1207, 1219 (1987) ("Congress does not intend sub silentio to enact statutory language that it has earlier discarded in favor of other language." ") (quoting Nachman Corp. v. Pension Benefit Guar. Corp., 446 U.S. 359, $392-93$ (1980) (Stewart, J., dissenting)). 
cal way, the legislative inaction arguments seem quite good, because they tell us something about actual legislative intent, which has traditionally been considered highly relevant when the Court interprets a statute. Yet in Johnson and other cases, Justice Scalia seizes this metaphor and criticizes it intensely. On the whole, I agree with his critique. While the inferences we draw from the inaction of my hypothetical Wadlington are reasonable, I do not believe that Congress is very much like Wadlington. It is different in three material ways: (1) Unlike Wadlington, Congress is a discontinuous decisionmaker. Wadlington is the same person, albeit older, year after year. Congress turns over every two years, and the "intent" that is constitutionally most relevant is the intent of the Congress that actually enacted the legislation. (2) Unlike Wadlington, Congress is a collective decisionmaker. While Wadlington may sometimes "be of two minds," Congress is always of two minds (the House and the Senate), and each of them contains many different minds. This makes it very difficult to figure out exactly what the intent of Congress is when it fails to do something. (3) Unlike Wadlington, Congress is a public decisionmaker. What Wadlington decides is of little moment, except to Wadlington and her household. What Congress decides has important consequences for many people and for our own political community. The public decisionmaking process in fact has several systematic flaws, and we need to be chary of exacerbating those flaws when we develop theories of interpreting Congress' decisions and indecisions. The legislative inaction cases may exacerbate some of those flaws.

The remainder of this part explores the implications of these three differences for the legislative inaction cases. To the extent these cases claim to tell us something about legislative expectations, they overstate their claim. To illustrate my criticisms, I shall use Johnson and three cases from Part I - Flood v. Kuhn, Sinclair, and Patterson. These are among the strongest cases for legislative inaction arguments, yet in each case those arguments provide less satisfying proofs of legislative intent than might appear at first glance. I conclude that legislative inaction rarely tells us much about relevant legislative intent. The most persuasive cases under this approach are the rejected proposal cases, such as Sinclair, where the enacting Congress in conference committee rejected a proposal similar to the interpretation rejected by the Court. (Ironically, of course, Sinclair has been overruled.) Not all rejected proposal arguments work, though, and I consider the rejected proposal arguments in Patterson and Flood unpersuasive. Reenactment arguments can sometimes be persuasive under an actual intent approach, and the reenactment argument in Patterson is not a bad one. 
Acquiescence arguments are almost never persuasive indicia of actual legislative intent, and their invocation in cases like Flood and Johnson only highlights flaws in the legislative process.

\section{A. Legislative Structures: Formalist Problems with Inferring Legislative Intent from Legislative Inaction}

An important formal problem with most of the legislative inaction cases is that they are inconsistent with the traditional proposition that the legislative "intent" relevant to statutory interpretation is the intent of the enacting Congress, not the continuing intent of subsequent Congresses. ${ }^{161}$ Doctrinally, this proposition underlies the rule that "subsequent legislative history" is not an authoritative source in statutory interpretation. In a long line of cases, the Supreme Court has held that " the views of a subsequent Congress form a hazardous basis for inferring the intent of an earlier one." "162 Formally, the job of Congress ends when it passes the statute, and "it is the function of the courts and not the Legislature, much less a Committee of one House of the Legislature, to say what an enacted statute means."163 Functionally, subsequent legislative history is highly unreliable and subject to strategic manipulation. ${ }^{164}$ "Thus, even when it would otherwise be useful, subsequent legislative history will rarely override a reasonable interpretation of a statute that can be gleaned from its language and legislative history prior to its enactment."165

161. Note that a growing body of literature argues that legislative intent is not the only thing courts will or ought to consider when they interpret statutes. R. DWORKIN, LAW'S EMPIRE 31354 (1986); Eskridge, Dynamic Statutory Interpretation, 135 U. PA. L. REV. 1479 (1987) [hereinafter Dynamic Statutory Interpretation]; see Aleinikoff, Updating Statutory Interpretation, 87 Mich. L. REV. 20, 108 (1988). My view is that historical legislative intent is relevant to statutory interpretation, for both formalist and functionalist reasons. Ongoing legislative consideration of an interpretive issue is, in my view, relevant information for a court to consider, but not as formally important as is the enacting legislature's intent.

162. Andrus v. Shell Oil Co., 446 U.S. 657, 666 n.8 (1980) (quoting United States v. Price, 361 U.S. 304, 313 (1960)); see also Southeastern Community College v. Davis, 442 U.S. 397, 411 n.11 (1979); W. ESKRIDGe \& P. Frickey, StatuTes aNd the Creation of Public Policy 757-59 (1987).

163. Pierce v. Underwood, 108 S. Ct. 2541, 2551 (1988).

164. Even contemporaneous legislative history may be unreliable and subject to manipulation. As legislators and lobbyists have begun to understand how much courts use legislative history, posturing and fabrication have become possible. The fight, if lost on the language of the statute, moves to the language of the committee report or perhaps to getting a scripted colloquy entered into the Congressional Record. The hope is that an unfavorable but likely interpretation will be limited, if not excluded, by the extra-statutory information.

165. Consumer Prod. Safety Commn. v. GTE Sylvania, Inc. 447 U.S. 102, 118 n.13 (1980); see also Clarke v. Securities Indus. Assn., 107 S. Ct. 750, 761 (1987); Shearson/American Express, Inc. v. McMahon, 107 S. Ct. 2332, 2342-43 (1987); South Carolina v. Regan, 465 U.S. 367, 378 n.17 (1984); Posner, Statutory Interpretation - in the Classroom \& in the Courtroom, $50 \mathrm{U}$. CHI. L. REV. 800, 809-10 (1983) (relying on postenactment statements "risk[s] repealing legislation ... without going through the constitutionally prescribed processes for repeal"); Wald, 
The Court's disapproval of subsequent legislative history is ultimately rooted in the procedural structures for statutory law found in the Constitution. Pursuant to articles I and VI, federal statutes are our supreme law (assuming they are constitutional), trumping and displacing the common law and state law. The supremacy of statutes, however, is accompanied by elaborate procedural requirements. Before something is an authoritative legislative enactment, entitled to supremacy, it must be passed by both chambers of Congress in the same form, and signed by the President (or passed over a veto). ${ }^{166}$ Thus, nonbinding resolutions, passed by both Houses of Congress but not presented to the President, are not formally entitled to authoritative weight in statutory interpretation. ${ }^{167}$

The acquiescence and most of the rejected proposal cases directly conflict with these propositions. If subsequent legislative statements directly supporting a statutory interpretation are not valid evidence, how can subsequent legislative silence, usually just indirectly supporting a statutory interpretation, be considered any more authoritative? As a formal matter, "in view of the specific and constitutional procedures required for the enactment of legislation, it would seem hardly justifiable to treat as having legislative effect any action or nonaction not taken in accordance with the prescribed procedures."168 Thus, in Flood v. Kuhn, the "positive inaction" the Court found critically important related to unsuccessful bills introduced between 1957 and 1965. ${ }^{169}$ The Court's conclusion that "Congress as yet has had no intention to subject baseball's reserve system to the reach of the antitrust statutes"170 is doctrinally suspect. In none of the more than fifty bills that Congress considered did both Houses agree; hence, there was no article I legislative enactment entitled to authoritative consideration by the Court. The only authoritative legislative enactment pertinent to the case was the original Sherman Act of 1890 that broadly prohibits restraints of trade in "interstate commerce," which baseball

Some Observations on the Use of Legislative History in the 1981 Supreme Court Term, 68 IowA L. REV. 195, 205 (1983) ("While follow-up congressional intent may become relevant if expressed in a positive legislative act, it is particularly risky to draw inferences from subsequent refusals to act."). But cf. Seatrain Shipbuilding Corp. v. Shell Oil Co., 444 U.S. 572, 596 (1980) (subsequent committee report may be given some weight when intent of enacting Congress is "obscure").

166. See INS v. Chadha, 462 U.S. 919 (1983) (enforcing the bicameralism and presentment requirements of Article I to invalidate legislative vetoes, in which one House of Congress could create law by overturning an agency decision); Grabow; supra note 9, at 746-48.

167. See Grabow, supra note 9, at 748 (citing recent example).

168. Cleveland v. United States, 329 U.S. 14, 22 n.4 (1946) (Rutledge, J., concurring).

169. Flood, 407 U.S. at 281-82. The Court also mentioned two statutes which expanded the antitrust exemption, but did not argue that the statutes or their legislative history had any direct bearing on the question of baseball's general exemption from the Sherman Act.

170. 407 U.S. at 283. 
has clearly been engaged in for some time, a fact explicitly recognized in Flood. 171

So, too, most of the primary rejected proposal cases - Albemarle Paper, North Haven Board of Education, and Blue Chip Stamps - are formally suspect, because the proposals were rejected after the relevant statute was enacted. Of course, this formal criticism does not apply to Sinclair, because in that case the rejected proposal was in connection with the original statute (LMRA section 301) being interpreted by the Court. The conference committee's rejection of an exception to the Norris-LaGuardia Act is, therefore, relevant legislative history, and not questionable subsequent history. The irony is that the Court overruled Sinclair eight years later in Boys Markets, Inc. v. Retail Clerks Union, Local 770. ${ }^{172}$ The latter opinion did not even mention the conference committee's rejection of the rule it adopted.

Insofar as they are said to be evidence of actual legislative intent, the legislative inaction arguments in Patterson are subject to the formalist objections discussed above. The argument that Congress has acquiesced in Runyon because it has not overturned it is of questionable formal relevance. The formal question is whether the text and legislative history of section 1981 itself support Runyon, a question that is harder for the Patterson petitioner. ${ }^{173}$ Similarly, the 1972 rejection of the Hruska amendment by the Senate, and the conference committee rejection of the House provision repealing section 1981 in employment discrimination cases, would not be relevant to the interpretation of Congress' intent in 1866.

The most persuasive argument would be that based upon section 1988 , as amended in 1976 by the Fees Act, because it is based upon a statute actually passed by Congress and formally entitled to supremacy. The reenactment cases are not subject to the formalist objections. The problem is that the Fees Act is not quite a reenactment of section 1981. It only builds upon section 1981, as interpreted in Runyon. Is this enough? Perhaps. "Subsequent legislation declaring the intent of an earlier statute is entitled to great weight in statutory construction."174 While the Fees Act does not state, "Section

171. 407 U.S. at 282 ("Professional baseball is a business and it is engaged in interstate commerce.").

172. 398 U.S. 235 (1970).

173. But not insuperable. Though $I$ have not researched the issue, I find the historical argument in the Petitioner's Brief, supra note 8, at 5-71, to be well-reasoned. See also Brief Amicus Curiae of Eric Foner, John H. Franklin, Louis R. Harlan, Stanley N. Katz, C. Vann Woodward \& Mary Frances Berry, Patterson (No. 87-107), which presents the views of leading historians on this issue.

174. Red Lion Broadcasting Co. v. FCC, 395 U.S. 367, 380-81 (1969); see also Consumer Prod. Safety Commn. v. GTE Sylvania, Inc. 447 U.S. 102, 118 n.13 (1980). 
1981 covers private as well as public discrimination," Congress included section 1981 because it wanted to encourage section 1981 lawsuits, just as it had encouraged Title VII lawsuits with a counsel fees provision. ${ }^{175}$ This intention rested upon the assumption that "the remedies available to the individual under Title VII are co-extensive with the individual's right to sue under the provisions of the Civil Rights Act of 1866, 42 U.S.C. $§ 1981 . " 176$ In short, Congress apparently was relying upon Runyon's interpretation of section 1981 when it amended section 1988, and that reliance is entitled to some consideration even under the formalist position outlined here. ${ }^{177}$

\section{B. Indeterminacy of Collective Intent: Realist Problems with Inferring Legislative Intent from Legislative Inaction}

Even if subsequent legislative inaction were formally relevant or authoritative evidence of legislative intent, there would be problems of inference. What, in fact, does the inaction mean? It was not difficult for us to infer that the individual Wadlington probably meant for Krattenmaker to fetch beef when she requested "soupmeat," at least after the first fetching. It is more difficult to make such probabilistic inferences for a large collection of people, especially when their decisionmaking is as structured as that in Congress. There are two dimensions to this problem. First, it is very hard to aggregate preferences in such a large collection of people. ${ }^{178}$ Very few of them express their views in legislative debates or committee reports, and when they cast their votes, it is not always easy to figure out what they mean by those votes.

Second, the structure of Congress makes it far more likely that something will not happen (inaction) than that it will (action). ${ }^{179}$ In-

175. See S. REP. No. 1011, 94th Cong., 2d Sess. 4, reprinted in 1976 U.S. CoDE CoNG. \& ADMIN. NEWS 5908 .

176. H.R. REP. No. 238, 92d Cong., 1st Sess. 19 (1971), quoted in H.R. REP. No. 1558, 94th Cong., $2 \mathrm{~d}$ Sess. 4 n.8 (1976). After quoting the language in text, the 1976 Fees Act House report observed: "That view was adopted by the Supreme Court in Johnson v. Railway Express Agency," 421 U.S. 454 (1975), which had squarely held that $\S 1981$ applied to private discrimination and was reaffirmed in Runyon.

177. Cannon v. University of Chicago, 441 U.S. 677, $686 \mathrm{n} .7$ (1979) (provision of counsel fees for Title IX lawsuits in congressional amendment to $\S 1988$ supports implication of a private cause of action under Title IX); see Haig v. Agee, 453 U.S. 280, 300-01 (1981) (congressional acquiescence is persuasive when Congress relied on interpretation in crafting other statutes); Dames \& Moore v. Regan, 453 U.S. 654, 678-82 (1981) (similar); Montana Wilderness Assn. v. United States Forest Serv., 655 F.2d 951 (9th Cir. 1981), cert. denied, 455 U.S. 989 (1982).

178. See K. Arrow, Social Choice and Individual Values (2d ed. 1963); D. Black, The Theories of Committees and Elections (1958); A. Sen, Collective Choice and Social Welfare (1970).

179. Standard works on the procedural obstacles to proposed legislation include R. DAVIDSON \& W. Oleszek, Congress aND Its Members (2d ed. 1985); W. Oleszek, Congres- 
ertia is the main reason for this phenomenon. The legislative agenda is severely limited; to gain a place on that agenda, a measure must not only have substantial support, but be considered urgent by key people (such as the President and/or the party leadership in Congress). ${ }^{180}$ Even if a proposal finds a place on the legislative agenda, it is usually doomed if there is substantial opposition, whether or not most legislators favor it, because of the variety of procedural roadblocks opponents may erect. A bill can effectively be killed by a hostile committee or subcommittee chair in either chamber, by a hostile House or Senate leadership, by a hostile Rules Committee in the House or by a filibuster in the Senate. Consequently, even if a majority of the members of Congress disagree with a judicial or administrative interpretation of a statute, it is very unlikely that they will be able to amend the statute quickly, if at all. 181

Given the variety of reasons, unrelated to the merits or legislative support, for the failure of an idea or a measure in Congress, Justice Frankfurter was surely right when he opined in Hallock that such considerations "indicate that we walk on quicksand when we try to find in the absence of corrective legislation a controlling legal principle."182 Consider the evidence in Flood v. Kuhn. On two occasions one chamber of Congress passed bills that would have expanded baseball's antitrust exemption to include other athletic activities, and based upon this evidence the Court reaffirmed its finding in Toolson that " 'Con-

sional Procedures and the Policy Process (2d ed. 1984); R. RIPley, Congress: Process and Policy (1975); R. RIPley \& G. Franklin, Congress, The Bureaucracy AND PUBlic Policy (4th ed. 1987).

180. See generally J. Kingdon, Agendas, Alternatives and Public Policies (1984).

181. An excellent recent example of this phenomenon is the Civil Rights Restoration Act of 1988, Pub. L. No. 100-259, 102 Stat. 28 (1988). The Act overturned Grove City College v. Bell, 465 U.S. 555 (1984), which interpreted Title IX of the Education Amendments of 1972 to bar sex discrimination only in programs which received federal aid, not in all programs of institutions receiving federal aid. From the beginning there were very few defenders of the Court's decision, and several bills were introduced to overturn it. 130 CoNG. REC. 3661-62 (1984). One bill passed the House but was killed by a Senate filibuster. 130 CoNG. REC. S4585 (daily ed. Apr. 12, 1984). (It takes sixty votes in the Senate to cut off a filibuster.) A similar Senate bill in the same Congress was tabled after parliamentary impasse near the end of the session. 130 CoNG. REC. S12640-43 (daily ed. Oct. 2, 1984). In the next Congress, the Senate bill was not reported out of committee. S. REP. No. 64, 100th Cong., 1st Sess. 3 (1988). Two committees favorably reported a House bill, H.R. REP. No. 963, 99th Cong., 2d Sess. parts 1 \& 2 (1986), but the bill was never called up before the full House. (Unless a bill is specially expedited by the Rules Committee, it is unlikely to be called up in its turn.) In the next Congress, fifty-one Senators sponsored a bill to overturn the decision, 133 CoNG. REC. S2249-56 (daily ed. Feb.19, 1987), yet it took a year before the bill passed the Senate, 134 CoNG. REc. S266 (daily ed. Jan. 28, 1988), and the House. 134 Cong. ReC. H597-98 (daily ed. Mar. 2, 1988). The President vetoed the bill, and Congress overrode the veto. 134 CoNG. REC. $\$ 2765$ (daily ed. Mar. 22, 1988); 134 CoNG. REC. H1071-72 (daily ed. Mar. 22, 1988). It is remarkable that it took four years of procedural maneuvering to overrule a Supreme Court decision that, from all I can tell, never had much support in Congress.

182. Hallock, 309 U.S. at 121. 
gress had no intention of including the business of baseball within the scope of the federal antitrust laws." "183 There are, however, several different inferences that could be drawn from Congress' reaction to the Court's decisions: ${ }^{184}$

(1) Legislators approved of the Court's decisions and were only divided on the question of whether and how far to expand them to other athletic activities.

(2) Legislators in one chamber approved of the Court's decisions only if they were applicable to all professional athletics (which the Court held was not the case), on grounds of fairness. Legislators in the other chamber either

(a) approved of the Court's decisions for baseball only and did not want them expanded to other sports, or

(b) disapproved of the Court's decisions entirely and did not want them expanded at all.

(3) Legislators in one chamber approved of the Court's decisions, while legislators in the other chamber did not care enough about the issue to consider it.

(4) Legislators in neither chamber approved of the Court's decisions, but on two occasions one chamber voted for an expansion of the decisions in order to placate the special interests of team owners in baseball and other sports. On each occasion, the chamber understood that the other chamber would not go along.

Of these possible inferences, only the first one supports Flood's conclusion that Congress "has no intention to subject baseball's reserve system to the reach of the antitrust statutes." Inferences two and four strongly cut against the Court's decision, because they suggest legislative unhappiness with the unequal treatment of baseball and other sports. The Court suggests no reason to prefer the first inference to the fourth, and there is every reason to believe that the first is less likely than the second and fourth together.

The problems with the acquiescence and rejected proposal arguments in Flood are generalizable, because Flood is a relatively strong case for their invocation. A similar analysis can be used in other cases. ${ }^{185}$ For example, the acquiescence and rejected proposal argu-

183. Flood, 407 U.S. at 285 (quoting Toolson v. New York Yankees, Inc., 346 U.S. 356, 357 (1953) (per curiam)). The Court also used this evidence to conclude that Congress has had no desire to disapprove of Federal Baseball legislatively. That is obvious but cuts against the Court's position unless it also concludes that Congress approved of the decision.

184. See H. HART \& A. SACKS, supra note 9, at 1395-96.

185. Farber, supra note 68 , at 10 , argues that "probability theory indicates that, no matter how many other causes of congressional silence may exist, silence is still a signal of congressional approval." He supports his assertion with an example using two urns, one with only white mar- 
ments in Patterson are even more vulnerable, as suggested by an analysis of Congress' refusal to cut back on the ambit of section 1981 in connection with its 1972 amendment to the Civil Rights Act of 1964. Start with Senator Hruska's proposed amendment in the Senate. The amendment did not single out section 1981, nor did it posit that section 1981 should be reinterpreted to apply only to public discrimination. ${ }^{186}$ Senator Hruska offered the amendment because then-current law permitted a "multiplicity of actions to be instituted against a respondent before a number of separate and distinct forums for the same alleged offense."187 While section 1981 was apparently one of the "multiplicity of actions" concerning Senator Hruska, neither he nor his amendment expressed an opinion on the ambit of section 1981. The Senate bill expanded Title VII to cover discrimination by state and local governments against their employees, and so section 1981 was a relevant statute however it was interpreted. Those voting against the Hruska amendment were, at most, following the dictates of the bill's sponsors not to remove section 1981 from the employment arena. ${ }^{188}$ In short, rejection of the Hruska amendment tells us little about what anyone thought about section 1981's application to private discrimination.

Assume, as the Court did in Runyon, ${ }^{189}$ that the vote on the

bles and another with half white, half black marbles. Id. at 10, n.38. We are prèsented with a white marble. Though we don't know which urn produced the marble, it is probably the first urn. "Similarly," Farber concludes, "although congressional silence could result from either congressional approval or other factors, it still increases the likelihood of congressional approval." Id. The flaw in this analysis is that Farber has stacked the urns, by giving us only two (Congress either approves or disapproves) and assuming there is an equal number of marbles in each (his inference doesn't work if the second urn has twice as many marbles as the first).

Consider a more realistic variation on Farber's example. White marbles indicate that Congress will not overturn (black marbles indicate that it will). Three urns represent Congress' possible attitudes toward an interpretation. Um 1 stands for Congress' positive approval of the interpretation and has four white marbles (there is no way Congress will overturn the interpretation). Um 2 stands for Congress' disapproval of the interpretation; it has two white and two black marbles (50-50 chance of overturning, depending on procedural obstacles). Urn 3 stands for Congress' apathy or ignorance of the interpretation; it has 44 white marbles and six black marbles (Congress may do something but very probably won't). We are presented with a white marble. Can we infer that it came from Urn 1 (Congress approves of the interpretation)? No. There is a $92 \%$ probability that it came from Urn 2 or 3 (Congress disapproved or was unaware). While Farber's argument is "brilliant," see Farber, The Case Against Brilliance, 70 MiNN. L. REV. 917 (1986), it is not persuasive.

186. See 118 CoNg. REC. 3173 (1972) (text of Hruska amendment).

187. Id. at 3172. One example of this "multiplicity" was that of a lawsuit by a black employee against an employer, pursuant to the Civil Rights Act of 1866, id. at 3173, but Senator Hruska did not explain whether the employer was private or public.

188. Additionally, those voting against the amendment may have thought it unnecessary, since modern principles of res judicata would protect companies against seriation employment discrimination lawsuits. See id at 3370 (Sen. Javits).

189. 427 U.S. at 174 n.11. Runyon characterized the defeat of the Hruska amendment as a referendum on the Alfred $H$. Mayer interpretation of the Civil Rights Act of 1866, which is not 
Hruska amendment was somehow a referendum on section 1981's applicability to private discrimination. The argument is still problematic. While Runyon correctly says that "Senator Hruska's proposed amendment was rejected," 190 it does not mention that the amendment failed on a tie vote - thirty-three Senators voting for it, and thirtythree Senators voting against it. ${ }^{191}$ Indeed, there were actually thirtyfour Senators on the floor voting in favor of the amendment, which means that a majority of those Senators present supported the amendment. But the thirty-fourth Senator announced that he was a live pair for an absent Senator. ${ }^{192}$ It is highly unusual for a Senator to agree to be a live pair when it affects the outcome, ${ }^{193}$ and I suspect that some deal had been worked out by the Senate Democratic leadership to save the bill from the Hruska amendment. ${ }^{194}$ In any event, with at least half the voting Senators agreeing with the Hruska amendment, Runyon's attempt to use it to prove legislative intent is questionable.

Although Runyon did not mention it, a better argument for its position would have been the rejection of a similar proposal by the conference committee that assembled the Equal Employment Opportunity Act in 1972. Like the Senate Labor \& Public Welfare Committee, the House Education \& Labor Committee had reported a bill which preserved existing remedies and refused to make Title VII the exclusive remedy for employment discrimination. ${ }^{195}$ Unlike its Senate counterpart, though, the House committee was unable to prevent its version from being amended. Indeed, the committee bill was replaced on the floor of the House with a substitute that contained

the case, for the reasons suggested in the text. For support, the Court quoted Senator Williams: " "It was recently stated by the Supreme Court in the case of Jones v. Mayer, that these acts [sections 1981 and 1983] provide fundamental constitutional guarantees.' " 427 U.S. at 174 n.11 (quoting 118 CONG. REC. 3371 (1972)). Apart from Senator Williams' confusion about the holding in Alfred H. Mayer (which interpreted $\S 1982$, not $\S 1981$ ), that quotation is odd support for the Court, since Senator Williams lumps together $\S \S 1981$ and 1983 and characterizes them as protecting "constitutional" rights - which are normally only applicable to public and not private discrimination. The one or two Senators who were really listening to Senator Williams might have assumed the opposite of the Court's point - that $\S 1981$, like $\S 1983$, applies only to public discrimination!

190. 427 U.S. at 174 n.11.

191. 118 CONG. REC. 3373 (1972) (roll call vote, listing Senators).

192. Id. at 3372 .

193. W. OLESZEK, supra note 179, at 184.

194. Indeed, the live pair, Senator Gambrell, moved for reconsideration, which allowed the leadership to muster its forces next time around. The motion was easily defeated, 37 Senators favoring reconsideration, 50 opposed. 118 CoNG. REc. 3965 (1972).

195. H.R. REP. No. 238, 92d Cong., 1st Sess. 18-19 (1971) (rejecting efforts within the committee to make Title VII the exclusive remedy for employment discrimination, and reaffirming the applicability of $\S 1981$ ). 
(inter alia) an exclusivity provision. ${ }^{196}$ In the conference committee, the House receded from its version, and the Senate nonexclusivity position prevailed. While Sinclair and Albemarle Paper suggest that this ought to be a decisive argument for the Runyon result, it is subject to some doubt, based upon a realistic appraisal of the legislative process.

As was the case with the failure of the Hruska amendment, we have no clear explanation from the official records for why the Senate position prevailed over the House position. The explanation probably was the conference committee's desire to have a broad range of federal and state remedies for employment discrimination. Such an explanation and the conference committee's choice of nonexclusivity are, of course, perfectly consistent with the view that section 1981 only covers public discrimination, because the final bill extended Title VII coverage to state and local employees. ${ }^{197}$ More importantly, there is a likely procedural explanation for why the Senate position prevailed. The custom, followed in 1972, is to appoint as conferees on important legislation members of the relevant committee in each chamber. ${ }^{198}$ The conference committee for the 1972 Act consisted of members of the House Education \& Labor Committee, a majority of whom had opposed the exclusivity provision in committee and on the House floor, ${ }^{199}$ plus members of the Senate Labor \& Public Welfare Committee, an overwhelming majority of whom had voted against the Hruska amendment. ${ }^{200}$ Given this composition, of course the conference committee was going to preserve all existing remedies. But the choice made by an unrepresentative collection of conferees (on this issue) ought not be given any significance in discerning the intent of Congress.

. 196. The House adopted the substitute by a close vote of 200 to 195.117 CoNG. REc. 32111 (1971).

197. Indeed, in its explanation of the expansion of Title VII to cover public employees, the House Committee said that "the individual's right to file a civil action in his own behalf, pursuant to the Civil Rights Act of 1870 and 1871, 42 U.S.C. $\$ \S 1981$ and 1983 is in no way affected." H.R. REP. No. 238, 92d Cong., 2d Sess., reprinted in 1972 U.S. CODE CONG. \& ADMIN. NEWS 2137,2154 . This is strange, since the report identifies $\S 1981$ with the 1870 Act, which only applied to state actors, and not the 1866 Act, which applied to private parties as well. However, the report, several sentences later, identifies $\$ 1981$ with the 1866 Act.

198. W. OleszeK, supra note 179, at 207. "Who gets named a conferee (or who is passed over) sometimes can be critical to conference outcomes." Id. at 209.

199. Of the 20 Representatives named to the Conference, 118 CoNG. REC. 5187 (1972), 11 (all but one of the Democrats) had voted against the Erlenborn substitute, which added the exclusivity provision. 117 CoNG. REC. 32111 (1971).

200. Of the 12 Senators named to the Conference, 118 CoNG. REc. 5184 (1972), 10 voted against the Hruska amendment. Id. at 3373. One conferee voted for the amendment, and one was absent. Id. at 3372 . 


\section{Dysfunctions in the Legislative Process: Systemic Problems with Inferring Legislative Intent from Legislative Inaction}

The analysis in this part has suggested that, on closer examination, the legislative inaction arguments in most of the leading cases do not often tell us much about relevant legislative intent. I want to conclude the analysis by raising a larger policy issue: If the Supreme Court seriously applies the various legislative inaction doctrines, it may be exacerbating dysfunctions that exist in the legislative process. In the previous section, I dealt with one dysfunction, inertia. Congress' failure to be more active in dealing with public problems is perceived by many to be a substantial institutional failing, and the Court's willingness to draw overbroad conclusions from Congress' lapses expands upon the already malign consequences of this dysfunction.

Another institutional dysfunction of Congress is suggested by analysis of the legislative inaction arguments in Flood and Johnson. In Flood, the baseball owners argued that since virtually all of the legislative activity after Toolson had sought to expand baseball's antitrust immunity to other sports, it would be anomalous for the Court to eliminate that immunity, ${ }^{201}$ and it is likely that this argument was a persuasive one to the Court. The Court itself in Johnson advanced a similar argument to defend its position that Congress' failure to overrule Weber represented acquiescence in the decision. ${ }^{202}$ Just before Weber, Congress had responded to an equally controversial Supreme Court interpretation of Title VII, General Electric Co. v. Gilbert. ${ }^{203}$ That case held that Title VII's sex discrimination prohibition did not apply to an employer's failure to provide pregnancy benefits as part of an otherwise comprehensive health care package; within two years, Congress overruled Gilbert through the Pregnancy Discrimination Act of 1978.204 One of the amici in Patterson argues that Congress' failure to overrule Runyon is particularly significant, given its willingness to overrule other judicial interpretations of civil rights statutes, such as Gilbert. 205

These arguments have a strong appeal. If one can show substantial congressional activity in a given subject area - civil rights or application of antitrust principles to professional sports - then concerns about legislative inertia and inactivity seem less persuasive. The prob-

201. Respondents' Brief at 33-36, Flood (No. 71-32).

202. $107 \mathrm{~S}$. Ct. at 1451 n.7.

203. 429 U.S. 125 (1976).

204. 42 U.S.C. § $2000 \mathrm{e}(\mathrm{k})$ (1982).

205. Lawyers' Committee Brief, supra note 8, at 11-13. 
lem with these arguments is that even when the legislature does respond, its pattern of response is biased in favor of well-organized (and frequently wholly unrepresentative) groups. Consider two influential lines of political theory, and then reconsider the arguments made in Flood, Johnson, and Patterson.

Public choice theory, the application of economic insights to political behavior, ${ }^{206}$ suggests several intriguing principles. Public choice theory assumes that legislators are primarily motivated by a desire to be reelected. Such legislators are confronted with the "dilemma of the ungrateful electorate" - that is, an axiom of human nature under which voters and interest groups will remember the things the legislator did to hurt them more strongly than they will remember the things done for their benefit. Given this calculus of human nature, legislators will try to avoid conflictual issues; hence, their activity will focus on passing laws that help as many organized groups as possible, without hurting other organized groups. This would not be so bad if organized groups represented a broad range of interests, but public choice theory also predicts that groups tend to organize in a selective and often arbitrary way. Groups are more likely to organize when they are small, wealthy, and well-defined; once they are formed, such groups will work intensely to seek concentrated benefits (such as subsidies) for themselves and to avoid concentrated costs (such as user fees). Conversely, groups will not so often organize to seek legislation that distributes benefits to the general population, or to avoid generally shared costs. Typically, the disorganized general public is not even aware of when its interests are being compromised.

The gloomy conclusion of public choice theory - prevalence of special interest groups and legislator reluctance to offend them - is made gloomier by the insights of institutional process theorists about "subgovernments."207 According to these theorists, decisions distributing benefits to private groups are generally made by subgovernments, that is, House and Senate committees and subcommittees, relevant bureaucrats and executive officers, and private lobbyists for the benefited groups. Because of their low visibility and ties to organized interests (which, public choice theory teaches, are formed selectively), subgovernments tend to pander to special viewpoints and are not necessarily broadly representative.

206. See Eskridge, Politics Without Romance: Implications of Public Choice Theory for Statutory Interpretation, 74 VA. L. REV. 275 (1988) [hereinafter Politics Without Romance]; Farber \& Frickey, The Jurisprudence of Public Choice, 65 TExAs L. REV. 873 (1987) (balanced analysis of the limitations of public choice theory).

207. See R. Ripley \& G. FrankLiN, supra note 179, at 1-31. 
Reconsider the post-Toolson legislative activity in this light. The obvious reason why the activity focused on expanding the antitrust exemption to other sports is that no one was pressuring Congress to eliminate baseball's exemption, while strong organized pressure was applied to expand it. Baseball owners were well-organized and would have lobbied hard against any effort to take away their exemption, and owners in other professional sports were just as well-organized to obtain similar treatment for their sports. These groups fit the classic public choice pattern - small, homogenous, and wealthy - as the groups most likely to organize. Those hurt by baseball's exemption the millions who bought overpriced tickets each year and watched the sport on television - were unlikely to organize because they were generally ignorant of their injury and because individual stakes were very small. Even baseball players, a smaller and discrete group harmed by the antitrust exemption (the reserve clause), were not politically organized until after 1966.208 Consequently, the relevant subgovernment between 1957 and 1965, when the legislative activity occurred, wanted only to help the owners, because they were virtually the only organized "players" in the legislative ballgame. There was no pressure on legislators to help consumers and ballplayers; because they were not well-organized, they were effectively marginalized in the political process. Under these circumstances, Congress was not going to overturn Toolson. Its failure to do anything says nothing about its approval of the gap in antitrust enforcement created in such a blundering fashion by the Court and, instead, represents a prudent reluctance to cave in to special interest demands to expand the exemption.

For similar reasons, Congress is highly unlikely to overturn Weber. The relevant subgovernment consists of well-organized minority and civil rights groups ${ }^{209}$ and sympathetic members of the Judiciary Committees in both Houses of Congress. ${ }^{210}$ So long as the civil rights

208. The Major League Players Association was formed in 1954, but it did not become a major force until after 1966. Players were not better organized, in part because they were just not politically alert and had substantially more allegiance to their teams (and hence to the owners of their teams) than to their group, before the 1960 s. In the 1970 s the players were much better organized and were able to eliminate the reserve clause through arbitration.

209. Note that blacks, the primary beneficiary group of Weber, are a classic group for political organization (now that barriers to political participation have been removed). While they are numerous, they are "discrete and insular," which facilitates their organization. See Ackerman, Beyond Carolene Products, 98 HARv. L. REV. 713 (1985).

210. The House Judiciary Committee has been chaired by liberal Representative Rodino in this time frame and has been controlled by liberal Democrats with close ties to the civil rights lobby. The Senate Judiciary Committee for six years was chaired by Senator Thurmond, once a bitter foe of civil rights and now at best acquiescent. Even in this period, the civil rights lobby could count on a committee majority (the Democrats, plus liberal Republican Senators Specter and Mathias) in key situations. 
lobby intensely favors Weber, very few members of Congress are going to tamper with it, and the legislative committees will fight them if they try. Conversely, there is no organized political demand to overturn Weber. Unions and employers (highly organized groups) benefit from Weber, because it allows them to escape potentially costly Title VII lawsuits. Those hurt by Weber - blue collar white males - are diffuse and ill-organized politically. In short, contrary to the Court's opinion in Johnson, the legislative response to Gilbert is not surprising, nor is the nonresponse to Weber. ${ }^{211}$ While both decisions were controversial, only Gilbert hurt a group active in the political process, and so it is not surprising that only it was overturned. ${ }^{212}$

Under this framework, Patterson is an intermediate case. Runyon's vulnerability falls between that of Gilbert and that of Weber. Like Weber, Runyon benefitted well-organized minority groups who have powerful allies in the relevant subgovernment. Like Gilbert, and unlike Weber, Runyon hurt well-organized employer groups, which disliked the broader employment discrimination relief afforded by section 1981. They were able to present their position to Congress in 1972 (when lower court decisions clearly signaled the coming of Runyon), and they lost.

This analysis suggests that in cases like Johnson and Flood the acquiescence argument is particularly questionable as a basis for inferring legislative intent. Acquiescence is the rule and not the exception, whatever Congress' feelings about a Supreme Court decision; and legislative overruling is as much controlled by political calculations as by any judgment on the merits. If the Court is going to make inferences about legislative intent based upon acquiescence, ${ }^{213} \mathrm{I}$ urge that the

211. I disagree with the characterization of my position by Farber, supra note 68, at 11 n.39. I posit two reasons why no bills were even introduced to overturn Weber: (1) groups benefitting from the decision were better organized than victims (the explanation Farber attributes to me), coupled with (2) the dilemma of the ungrateful electorate and the strong aversion most legislators have to antagonizing important interest groups (an explanation Farber does not attribute to me).

212. I speak only in terms of probability. I am undertaking an empirical study of congressional responses to judicial statutory interpretations and have discovered that Congress does often respond to judicial decisions; though the legislative response is biased, it is not perfectly predictable. Recall the long fight to overturn Grove City, recounted in note 181 supra. The opposition of the President and other important public figures, based in part on ideological grounds, is one of the political imponderables that the public choice calculations do not precisely anticipate. See Eskridge, Politics Without Romance, supra note 206, at 319-22.

213. The analysis also raises some questions (albeit less serious ones) about the reenactment cases. When Congress reenacts a statute, or enacts related legislation (such as the Fees Act), it has few incentives to reexamine issues "settled" by Supreme Court decisions. Unless virtually all of the relevant organized groups agree that the Court's decision is wrong or unless the groups favoring the Court's decision can be placated in the logrolling process, tampering with the Court's decision will add unnecessary complications to the process of enactment, which is hard enough as it is. 
Court consider whether the "losers" in the initial interpretation had effective access to the political process to urge reconsideration. If they did not - as in Flood and Johnson - then the Court should be more reluctant to find any kind of legislative approval of the decision. In my view, this reluctance does not extend to the issue in Patterson, because the losers in Runyon were well organized and had their opportunity to make their case before Congress.

\section{The Relevance of Legislative Inaction: The Presumed Correctness of BuIlding Block INTERPRETATIONS}

Based upon the arguments in Part II, I believe that legislative inaction usually tells us very little about actual legislative intent. If my skepticism about the usefulness of legislative inaction as evidence of legislative intent is correct, then what can be made of the dozens of Supreme Court cases that rely on legislative inaction as positive evidence in statutory interpretation? Are they all wrong? Their rhetoric about legislative intention is subject to question if they are referring to "actual intent," but the cases can be explained by reference to a better idea, "presumed intent." My thesis is that what the Court is doing in these cases is to place upon Congress the institutional burden of responding to "building block" agency and judicial interpretations of statutes when Congress disagrees with them. Building block interpretations, as I am using the term, are authoritative, well-settled interpretations upon which public and/or private parties reasonably rely to carry out their roles under the statute. If Congress does nothing, the Court feels free to presume (rebuttably of course) that an agency and/ or judicial building block interpretation is the correct one. This presumed intent approach explains the cases pretty well and is consistent with our constitutional traditions. I believe there are normative problems with this descriptive model and argue, further, that the legislative inaction doctrines ought to be applied somewhat more cautiously than they have been in the past. These normative problems do not apply to Patterson, however, and I fully endorse their application to reaffirm Runyon.

\section{A. Rethinking the Legislative Inaction Cases: Presumed Intent and the Legislative Burden of Response}

Although the rhetoric of the legislative inaction cases usually emphasizes legislative intent, as an actual collective intent like that of my hypothetical Wadlington, there is no inherent reason why the legal significance of legislative inaction must be tied to actual intent. To the 
contrary, the significance of inaction in legal doctrine is not necessarily based upon an actor's actual intent anyway, but typically is based upon the actor's failure to fulfill a legally defined duty. For example, criminal liability in Anglo-American law does not attach simply because an actor fails to save a dying person, even if the actor's intention is malicious - unless there is a statutory or common law duty for the actor to do something. ${ }^{214}$ In Anglo-American contract law, silence is usually not acceptance of an offer even if intended to be - unless the parties' relationship or a statute has created a duty to respond negatively if the offeree wants to decline. ${ }^{215}$ Perhaps the best public law example is the President's use of the veto power. If the President does not veto a bill passed by Congress within ten days, the inaction is deemed an approval of the bill, which becomes law whatever the President's actual intent or the reason for the President's failure to act. ${ }^{216}$

One reading of the legislative inaction cases is that once courts, the executive, or an agency has interpreted a statute, the burden is upon Congress to respond to the interpretation if it disagrees with it. If Congress does nothing to disturb the interpretation, the Court is free to presume that the interpretation was correct. This reading of the legislative inaction cases often appears in their rhetoric. Thus, the Court sometimes states the reenactment doctrine: "Congress is presumed to be aware of an administrative or judicial interpretation of a statute and to adopt that interpretation when it re-enacts a statute without change."217 And the acquiescence doctrine: "But once an agency's [or the Court's] statutory construction has been 'fully brought to the attention of the public and the Congress,' and the latter has not sought to alter that interpretation although it has amended the statute in other respects, then presumably the legislative intent has

214. See generally Kirchheimer, Criminal Omissions, 55 Harv. L. Rev. 615 (1942); Kleinig, Criminal Liability for Failures To Act, 49 LAw \& ConTEMP. ProBS., Summer 1986, at 161; Robinson, Criminal Liability for Omissions: A Brief Summary and Critique of the Law in the United States, 29 N.Y.L. Sch. L. REv. 101 (1984).

215. See Restatement (SECOND) OF ConTRACTS $\S 69$ (1) (1979); Comment, The Language of Offer and Acceptance: Speech Acts and the Question of Intent, 74 CALIF. L. REV. 189, 217-20 (1986).

216. U.S. CoNST. art. I, $\S 7$. This constitutional duty does not inhere when Congress is in recess. Cf. Barnes v. Kline, 759 F.2d 21 (D.C. Cir. 1985), vacated as moot, 107 S. Ct. 734 (1987) (President is bound by ten-day rule during intra-session congressional recesses).

217. Lorillard v. Pons, 434 U.S. 575, 580 (1978) (emphasis added); see Pierce v. Underwood, 108 S. Ct. 2541, 2551 (1988) (following Lorillard presumption instead of language of House committee report); Kelly v. Robinson, 107 S. Ct. 353, 359 (1986) (" if Congress intends for legislation to change the interpretation of a judicially created concept, it makes that intent specific' ") (quoting Midlantic Natl. Bank v. New Jersey Dept. of Envtl. Prot., 474 U.S. 494, 501 (1986)); Girouard, 328 U.S. at 76 (Stone, C.J., dissenting) ("It is the responsibility of Congress, in reenacting a statute, to make known its purpose in a controversial matter of interpretation of its former language."). 
been correctly discerned." 218 And the rejected proposal rule: "One must assume that a deliberate policy decision informed Congress' rejection of these alternatives in favor of the language presently contained in [the statute]."219 The presumption suggested by this rhetoric can be rebutted by showing that there was no authoritative interpretation of which Congress should have been aware, or that Congress did in fact send some signals of disapproval. The presumption becomes conclusive by showing that Congress did in fact approve of the interpretation.

If the relevant intent is a presumed intent arising out of an institutional responsibility, what is the source of the responsibility? The apparent policy basis for this responsibility is our legal system's desire for continuity in the law, a concern that also animates stare decisis. 220 Continuity is desirable for at least three reasons. ${ }^{221}$ First, it contributes to our overall sense of security and to the legitimacy of law as something that does not unduly vacillate. Second, persons subject to legal rules often rely on those rules when structuring their activities. If the rules changed abruptly and constantly, their reliance interests would be destroyed. Third, public decisionmakers often rely on those rules when establishing or changing other rules. Changing one rule might then unhinge other rules built upon it.

Given these policies, the presumption of correctness should apply to interpretations that subserve the policies of continuity. Hence, the strongest case for application of the presumption is for a "building

218. United States v. Rutherford, 442 U.S. 544,554 n.10 (1979) (emphasis added) (quoting Apex Hosiery, 310 U.S. at 489); see Monessen S.W. Ry. v. Morgan, 108 S. Ct. 1837, 1844 (1988) ("We are unwilling in the face of such congressional inaction to alter the long-standing apportionment between carrier and worker of the costs of railroading injuries. If prejudgment interest is to be available under the FELA, then Congress must expressly so provide."); Guardians Assn. v. Civil Serv. Commn., 463 U.S. 582, 621 (1983) (Marshall, J., dissenting in part) ("[I]t is appropriate to attribute significance to [legislative] inaction where an administrative interpretation involves [salient] issues' ... and Congress has not acted to correct any misinterpretation of its objectives despite its continuing concern with the subject matter . . . ."); North Haven Bd. of Educ. v. Bell, 456 U.S. 512, 535 (1982) (similar); Dames \& Moore v. Regan, 453 U.S. 654, 686 (1981) ("Past practice does not, by itself, create power, but "long-continued practice, known to and acquiesced in by Congress, would raise a presumption that the [action] had been [taken] in pursuance of its consent." ") (quoting United States v. Midwest Oil Co., 236 U.S. 459, 474 (1915)).

219. NLRB v. Robbins Tire \& Rubber Co., 437 U.S. 214, 248 (1978) (Powell, J., concurring in part \& dissenting in part) (emphasis added); see Sinclair Ref. Co. v. Atkinson, 370 U.S. 195, 210 (1962) (When repeal of a specific statutory section is urged upon Congress and rejected in conference committee, "the normal expectation is that courts will be faithful to their trust and abide by that decision.").

220. The legislative inaction cases are very much connected with stare decisis, because many of them deal with the Supreme Court's statutory interpretations. But the cases also deal with Congress' response to settled statutory interpretations by the executive, agencies, and lower courts.

221. See generally Moragne v. States Marine Lines, Inc., 398 U.S. 375 (1970). 
block interpretation." Following the policy reasons for continuity in law, a building block interpretation has the following characteristics. First, it must be an authoritative or settled interpretation, setting a firm direction for the statute's development. Hence, a lower court interpretation not followed by other courts, or an informal agency practice would not be a building block interpretation. Second, it must be one on which parties subject to the statute have (probably) relied in structuring their conduct. A widely ignored interpretation is not a building block one. Third, it must be one upon which public decisionmakers have (apparently) relied in developing further legal rules.

Conversely, the presumption of correctness does not inhere in a judicial, executive, or agency interpretation which is "unsettled," namely, one that is not authoritative and has not been the basis of private or public reliance. (Now, such an interpretation may in fact be correct, but it is entitled to no presumption.) Obviously, most interpretations are intermediate cases, neither building blocks nor unsettled. For example, a lower court interpretation upon which private parties but not public decisionmakers have relied is not quite a building block interpretation, but it is entitled to some presumption of correctness.

My reading of the cases is largely descriptive. I think it adequately accounts for the Court's concerns in the legislative inaction cases and for most of the apparently anomalous results reached by the Court. For example, contrast the Court's application of the acquiescence rule in Monell with that in Johnson. ${ }^{222}$ In Monell, the Court overruled a seventeen-year-old precedent (Monroe), notwithstanding congressional inaction, while in Johnson the Court reaffirmed an eight-year-old precedent (Weber), based upon congressional acquiescence. My explanation for the different results is that the Court considered Monroe an unsettled precedent, and Weber a building block one: Monell gave four reasons why it would be unjustified to " "place on the shoulders of Congress the burden of [correcting] the Court's own error." "223 The first three reasons parallel the three continuity values underlying the presumption of correctness: Monroe was inconsistent with the Court's practice both before and after 1961, Congress had not relied on Monroe and in fact had assumed in the 1976 Fees Act that Monroe did not really protect local governments from suit, and there was no justi-

222. Dissenting in Johnson, $107 \mathrm{~S}$. Ct. at 1473, Justice Scalia argued that if Congress' failure to overturn Weber could be taken by the Court as evidence that the decision is correct, the same argument ought to have persuaded the Court that Monroe is correct.

223. 436 U.S. at 695-701 (quoting Girouard, 328 U.S. at 70); see 436 U.S. at 708-13 (Powell, J., concurring). 
fiable private reliance. ${ }^{224}$ I read these to say that there were no continuity-of-law justifications for affording Monroe a presumption of correctness. The fourth reason given in Monell was " "that it appear[ed] beyond doubt from the legislative history of the 1871 statute that [Monroe] misapprehended the meaning' " of the statute.225 That is, even if the presumption of correctness had applied, the Court might still have- overruled Monroe because its error was so clear. Justice Scalia's dissenting opinion in Johnson sought to characterize Weber as similarly aberrational, ${ }^{226}$ but his arguments were forcefully rebutted by Justice Stevens' concurring opinion. ${ }^{227}$ Justice Stevens argued that Weber is now an important part of the fabric of the law, relied upon by unions and employers seeking to bring their workforces into compliance with Title VII; the Court has been building upon Weber in a series of cases that have spelled out in more detail the contours of that decision. Though Weber is a recent decision and is not without analytical problems, those problems come nowhere near to challenging the presumed correctness of such a building block case. ${ }^{228}$

For a more difficult pair of cases, consider Sinclair and Boys Markets. Sinclair's reliance on the Taft-Hartley conference committee's rejection of the House proposal to curtail the Norris-LaGuardia Act seems like a decisive argument, because the Congress enacting the statute being interpreted squarely considered the issue and reached formal agreement. Nonetheless, Boys Markets not only denied that argument, but also rejected an argument based upon post-1962 legislative acquiescence in Sinclair. 229 Under the Court's actual intent approach, these cases seem entirely anomalous: Surely Sinclair, and not Boys Markets, accurately discerned the actual legislative intent. But my presumed intent approach suggests a plausible way to reconcile the two cases, as the Court itself recognized. "It is precisely because Sinclair [in 1970] stands as a significant departure from our otherwise consistent emphasis upon the congressional policy to promote the

224. 436 U.S. at 695-700; see Eskridge, Overruling Statutory Precedents, supra note 9, at 1382-83, 1393-96.

225. 436 U.S. at 700 (quoting Monroe, 365 U.S. at 192 (Harlan, J., concurring)); see 436 U.S. at 66489 (elaborate analysis of original legislative intent).

226. 107 S. Ct. at 1471-76 (Scalia, J., dissenting).

227. 107 S. Ct. at 1457-60 (Stevens, J., concurring); see Eskridge, Overruling Statutory Precedents, supra note 9, at 1411-14. The Court's only response to Justice Scalia was invocation of the acquiescence rule, $107 \mathrm{~S}$. Ct. at $1450 \mathrm{n} .7$, but presumably the Court generally agreed with Justice Stevens' favorable characterization of Weber.

228. For an extended analysis of why I think Weber is a building block case and (indeed) why I think Weber was correctly decided, see Eskridge, Dynamic Statutory Interpretation, supra note 161 , at 1492-94.

229. Boys Markets, 398 U.S. at 240-42. 
peaceful settlement of labor disputes through arbitration . . . that we believe Sinclair should be reconsidered."230 In 1962, Sinclair was a persuasive decision because the action of the conference committee was consistent with fundamental labor policies, and the rejected proposal was inconsistent with them. The committee's action created a presumption of legislative intent because it sustained the longstanding anti-injunction policy of the Norris-LaGuardia Act against incursion by the newer policy of encouraging labor arbitration. That latter policy was in large part judicially created in a series of decisions handed down only a few years before Sinclair. ${ }^{231}$ But by 1970, when Boys Markets was decided, the policy subordinated in Sinclair had become fundamental (enforceable labor arbitration became the linchpin of national labor policy), and Sinclair's preferred policy had become less urgent. Additionally, it had become clear by 1970 that Sinclair was interfering with state court injunctions compelling arbitration, which went beyond the concerns of the Norris-LaGuardia Act. ${ }^{232}$

Finally, return to Flood, which is very hard to defend under an actual intent approach. Under the presumed intent approach, it remains marginal but is at least defensible. Was Federal Baseball/Toolson a building block interpretation triggering a congressional burden of response if it disagreed? Yes and no. Yes, in the sense that the interpretation had been in place for half a century and had created substantial private reliance interests. No, in the sense that the interpretation was increasingly inconsistent with the Supreme Court's overall antitrust jurisprudence, and even inconsistent with the Court's application of antitrust law to professional athletics. The dissenting Justices stressed the inconsistency with general antitrust law, while the majority stressed the longstanding interpretation and current reliance. Under the descriptive approach outlined here, Federal Baseball/Toolson was entitled to a weak presumption of correctness, which was apparently enough to save these decisions given the close case on the merits. ${ }^{233}$

230. 398 U.S. at 241.

231. See Steelworkers v. American Mfg. Co., 363 U.S. 564 (1960); Textile Workers v. Lincoln Mills, 353 U.S. 448 (1957).

232. See Boys Markets, 398 U.S. at 242-49; Eskridge, Overruling Statutory Precedents, supra note 9 , at $1390-91$.

233. In the eyes of the Justices, anyway. Professor Stephen Ross has suggested to me that there were in 1972 several very good current-policy arguments in favor of preserving baseball's antitrust exemption. Hence, Justice Blackmun (the author of Flood and apparently a great baseball fan) and perhaps the other Justices were persuaded by the arguments, which I hope Professor Ross publishes. (The vote in Flood was five to three.) 


\section{B. Problems with the Legislative Inaction Cases, Even Under the Presumed Intent Theory}

My explanation of the Court's legislative inaction cases, focusing on the presumption of correctness for building block interpretations that Congress does not overrule, is only descriptive. The question remains: If this really does capture what the Court is doing, is it normatively defensible? The main problem I have with the presumed intent approach is that it, like the actual intent approach, exacerbates dysfunctions in the legislative process. As I argued in Part II, ${ }^{234}$ the legislative process is heavily inertial, and many interests are not effectively heard. I am concerned that the presumption of correctness might overprotect interpretations benefitting well-organized interests, too often at the expense of the general welfare. That is, once an organized interest wrests a favorable interpretation from the courts or a captured agency and of course relies on it, it will very probably be able to rely on the presumption of correctness, because its interpretation is a building block one and Congress is unlikely to express disapproval, given the interest group's ability to mobilize opposition to any effort to change the interpretation legislatively. Conversely, if a judicial or administrative interpretation hurts the interests of the same well-organized group, the group will often have a fighting chance to obtain a legislative overruling.

In short, the legislative inaction cases - however they are explained - have an asymmetrical, and unfair, impact on the development of legal rules. For this reason, I should urge that the presumption of correctness should be a weak one if the Court perceives that interests hurt by the building block interpretation do not have effective access to the political process. For me, this concern vitiates the use of legislative inaction in Flood, and I disagree with its result.

A second, and related, problem I have with the Court's practice in the legislative inaction cases is that it may foster or preserve obsolescent statutory interpretations, because the practice on the whole overvalues reliance interests and the historical continuity of one line of interpretation, to the detriment of the present coherence and fairness of our law. Again, Flood is an example of this phenomenon. Another is Monessen Southwestern Railway v. Morgan, ${ }^{235}$ decided at the close of the 1987 Term. Monessen interpreted the Federal Employers' Lia-

234. See text at notes 201-13 supra.

235. 108 S. Ct. 1837 (1988). 
bility Act (FELA) ${ }^{236}$ not to allow plaintiffs prejudgment interest as part of their damages awards. The Court argued that when FELA was enacted in 1908 the common law did not permit prejudgment interest in suits for personal injury or wrongful death and that the statute's failure to provide for such interest suggested an original intent not to include it. ${ }^{237}$ Additionally, the Court relied on Congress' failure to overturn the virtually uniform line of federal and state decisions holding that FELA does not permit prejudgment interest and on Congress' rejection of a proposal to amend the general federal interest statute to include prejudgment interest across the board. The Court suggested that this somehow tells us something about legislative intent, ${ }^{238}$ but the basic message of the opinion was that the Court was "unwilling in the face of such congressional inaction to alter the longstanding apportionment between carrier and worker of the costs of ... injuries. If prejudgment interest is to be available under the FELA, then Congress must expressly so provide."239

A dissenting opinion in Monessen argued that FELA's compensatory purposes are ill-served by denying claimants prejudgment interest on out-of-pocket losses, for that denies the claimant the make-whole remedy intended by Congress. ${ }^{240}$ As to the Court's legislative silence arguments, the dissenting Justices argued that even in 1908 the common law rule was being criticized as inconsistent with the compensatory purposes of tort law, and today's common law endorses prejudgment interest on out-of-pocket losses. ${ }^{241}$ Also, they argued that the "consistent judicial interpretation" of FELA was unpersuasive, because most of the decisions engaged in no meaningful analysis of the subject, and several recent ones that did analyze it recognized the "excellent case" to be made for prejudgment interest. ${ }^{242}$ " "We do not expect Congress to make an affirmative move every time a lower. court indulges in an erroneous interpretation,' " sniffed the dissenters. ${ }^{243}$

Monessen is arguably consistent with the Court's legislative inac-

236. 35 Stat. 65 (codified as amended at 45 U.S.C. $\$ \S 51-60$ (1982)).

237. $108 \mathrm{~S}$. Ct. at 1843. Especially since Congress in FELA abrogated several other common law doctrines of the era.

238. "Congress' failure to disturb a consistent judicial interpretation of a statute may provide some indication 'that Congress at least acquiesces in, and apparently affirms, that [interpretation].'" 108 S. Ct. at 1843-44 (quoting Cannon v. University of Chicago, 441 U.S. 677,703 (1979)).

239. 108 S. Ct. at 1844.

240. $108 \mathrm{~S}$. Ct. at $1847-49$ (Blackmun, J., concurring in part and dissenting in part).

241. $108 \mathrm{~S}$. Ct. at $1848-49$.

242. 108 S. Ct. at 1848 n.3.

243. 108 S. Ct. n.3 (quoting Jones v. Liberty Glass Co., 332 U.S. 524, 533-34 (1947)). 
tion cases because the interpretation denying prejudgment interest was so longstanding and relatively unbroken as to justify at least a weak presumption of correctness. ${ }^{244}$ But even if this is the case, Monessen illustrates a tendency of the legislative inaction cases to perpetuate legally obsolescent rules. That, in turn, owes much to the ambiguity of the underlying policy - continuity in law. There are two kinds of continuity in law, vertical and horizontal. The Monessen majority emphasized "vertical continuity," that is, the consistency of interpretation over time, for just the one issue. The dissent emphasized "horizontal discontinuity," that is, the inconsistency of denying FELA claimants prejudgment interest with the evolving purposes of FELA, the modern consensus that prejudgment interest is often necessary to assure compensatory relief, and the Court's willingness in other statutes to infer prejudgment interest. I believe that both types of continuity are important. Vertical continuity is often necessary to protect reliance interests and predictability of legal rules, but horizontal continuity is often necessary to effectuate dynamic statutory goals and assure overall fairness. When there is a clash between the values of vertical and horizontal continuity, I should often favor horizontal continuity. Hence, I believe the Monessen dissent had the better arguments.

My third concern with the presumptive intent approach to the legislative inaction cases is that it may sometimes slight actual legislative intent. In Pierce v. Underwood, ${ }^{245}$ also decided at the end of the 1987 Term, the Court interpreted the Equal Access to Justice Act of 1980 (EAJA), ${ }^{246}$ which provides that in civil litigation brought by or against the United States, federal courts shall award the prevailing party (but not the United States) its attorney's fees and other expenses, "unless the court finds that the position of the United States was substantially justified or that special circumstances make an award unjust."247 Based upon language in the House and Senate committee reports, and

244. The lower court interpretation in which Congress "acquiesced" was not a classic building block interpretation, because it was not entirely authoritative (i.e., there was no Supreme Court holding) and did not clearly create private reliance interests (though there may have been insurance assumptions). Cf. Norfolk \& Western Ry. v. Liepelt, 444 U.S. 490 (1980) (no acquiescence in longstanding lower court practice in FELA cases). On the other hand, the interpretation was not unsettled, either. The lower court cases were all but unanimous, and there may have been congressional reliance on them when the general prejudgment interest proposal was rejected. At most, the lower court interpretation was entitled to a weak presumption of correctness - a presumption that, I should have thought, is rebutted by its inconsistency with the statutory policy of make-whole relief.

245. 108 S. Ct. 2541 (1988).

246. Pub. L. No. 96-481, 94 Stat. 2325 (codified as amended and reenacted at 28 U.S.C. $\S 2412$ (1982 \& Supp. 1987)).

247. 28 U.S.C. $\S 2412$ (d)(1)(A) (1982 \& Supp. 1987). 
in the 1980 conference report, most of the federal circuits interpreted the statute to impose fees on the United States only when its position was not justified in the substance or in the main, that is, to a degree that would satisfy a reasonable person. ${ }^{248}$ In 1984, the District of Columbia Circuit rejected the prevailing test and held that the United States had to show something more than mere reasonableness to forestall the imposition of fees. ${ }^{249}$ In 1985 Congress reenacted the statute, using precisely the same language. The House report for the 1985 reenactment, however, opined that "'substantial justification' means more than merely reasonable" and that the lower court decisions accepting a reasonableness standard were wrong. ${ }^{250}$ Although Underwood cited no other evidence of legislative intent in the 1985 reenactment of the statute, it found this relatively clear committee language insufficient to rebut the presumption that the general trend in lower court interpretations was the one intended by Congress. ${ }^{251}$

An initial problem with decisions like the one in Underwood relates to overall interpretive methodology. Traditionally, actual legislative intent has been considered the lodestar of statutory interpretation, ${ }^{252}$ and a number of recent scholars have argued that original legislative intent is usually the only relevant criterion for interpreting a statute. ${ }^{253}$ The concept of presumed intent, based upon the policy concerns underlying the legislative duty to respond, might be inconsistent with this traditional understanding. I do not find this very problematic, though, because the traditional focus is an oversimplification of what statutory interpretation involves. ${ }^{254}$ For example, judicially created policy presumptions, often called clear statement rules, are not new to statutory interpretation. ${ }^{255}$ There are literally dozens of them, including the rule of lenity, that penal statutes should be interpreted nar-

248. See Underwood, $108 \mathrm{~S}$. Ct. at 2550 (citing cases).

249. Spencer v. NLRB, 712 F.2d 539, 558 (D.C. Cir. 1983), cert. denied, 466 U.S. 936 (1984).

250. H.R. REP. No. 120, 99th Cong., 1st Sess. 9 (1985).

251. $108 \mathrm{~S}$. Ct. at $2550-51$.

252. See $2 A$ N. SiNGER, supra note $10, \S 45.05$.

253. See, e.g., R. Posner, The Federal Courts: Crisis ANd Reform 286-93 (1985); Merrill, The Common Law Powers of Federal Courts, 52 U. CHI. L. REV. 1 (1985).

254. See Eskridge, Dynamic Statutory Interpretation, supra note 161; Patterson, Interpretation in Law - Toward a Reconstruction of the Current Debate, 29 VILL. L. REV. 671 (1984). Indeed, Judge Posner, who generally seeks original or reconstructed legislative understandings when interpreting statutes, supra note 253 , has recognized an increasing number of exceptions to that rule. See Posner, The Decline of Law as an Autonomous Discipline: 1962-1987, 100 HARv. L. REV. 761, 774-77 (1987); Posner, Legal Formalism, Legal Realism and the Interpretation of Statutes and the Constitution, 37 CASE W. RES. L. REV. 179 (1986).

255. See W. EskrIDGE \& P. FrICKEY, supra note 162, at 655-96; Eskridge, Public Values in Statutory Interpretation (May $1988 \mathrm{draft}$ ) (forthcoming). 
rowly in favor of the defendant when they are ambiguous; 256 the presumption against congressional diminishment of the historic police powers of the states; ${ }^{257}$ and the presumption against waiver of sovereign immunity; 258 to list just a few. Like the presumption of correctness when Congress fails to disapprove of a building block interpretation, these well-established rules presume a congressional intent, based upon important national policies (fair notice to criminal defendants, federalism, sovereign immunity). " "The normal rule of statutory construction," "the Court emphasized just last Term, " 'is that if Congress intends for legislation to change the interpretation of a judicially created concept, it makes that intent specific." "259

An even closer doctrinal relative to the presumption analyzed here is the special stare decisis rule for statutory precedents. The Court is often more reluctant to overrule a statutory precedent than a constitutional or common law precedent. ${ }^{260}$ The Court gives various reasons for what I call the "super-strong presumption against overruling statutory precedents." The most popular one is that when the Court misinterprets a statute, Congress is the better forum for correcting the error. This is simply another way of saying: Once the Court interprets a statute, Congress has the burden of response if it disagrees; if it does not respond, the Court can presume (as it did in Flood, Runyon, and Johnson) that its interpretation was correct. ${ }^{261}$ While I think that the

256. "[W] $]$ hen choice has to be made between two readings of what Congress has made a crime, it is appropriate, before we choose the harsher alternative, to require that Congress should have spoken in language that is clear and definite." United States v. Universal C.I.T. Credit Corp., 344 U.S. 218, 221-22 (1964), quoted in United States v. Campos-Serrano, 404 U.S. 293, 297 (1971); see McNally v. United States, 107 S. Ct. 2875, 2881 (1987) (if Congress wishes mail fraud statute to have broad reach, "it must speak more clearly than it has").

257. The Court will "start with the assumption that the historic police powers of the states were not to be superseded by the Federal Act unless that was the clear and manifest purpose of Congress." Rice v. Santa Fe Elevator Corp., 331 U.S. 218, 230 (1947), quoted in Ray v. Atlantic Richfield Co., 435 U.S. 151, 157 (1978); see Rose v. Rose, 107 S. Ct. 2029, 2041 (1987) (O'Connor, J., concurring in the judgment); Kelly v. Robinson, $107 \mathrm{~S}$. Ct. 353, 358-60 (1986).

258. Because " " $[t]$ he United States, as sovereign, is immune from suit save as it consents to be sued," " a waiver of federal government immunity in a statute must be " "unequivocally expressed." " United States v. Mitchell, 445 U.S. 535, 538 (1980); see Library of Congress v. Shaw, 106 S. Ct. 2957, 2961 (1986). Similarly, as to immunity for states, "Congress must express its intention to abrogate the Eleventh Amendment in unmistakable language in the statute itself." Atascadero State Hosp. v. Scanlon, 473 U.S. 234, 243 (1985).

259. Kelly v. Robinson, 107 S. Ct. 353, 359 (1986) (emphasis added) (quoting Midlantic Natl. Bank v. New Jersey Dept. of Envtl. Prot., 474 U.S. 494, 501 (1986)).

260. Levi, An Introduction to Legal Reasoning, 15 U. CHI. L. REv. 501, 540 (1948); see Eskridge, Overruling Statutory Precedents, supra note 9, at 1363 \& n.12 (citing authorities), 1364 69 (tracing history and rationales).

261. I demonstrated in Overruling Statutory Precedents, supra note 9, that the Court departs from this super-strong presumption quite often. My argument was that the Court should adopt an evolutive approach to overruling statutory precedents, parallel to the building block policy theory advanced in this article. 
Court's reluctance to overrule statutory precedents is too strong (just as I believe the Court relies too often on legislative inaction), neither I, nor other critics, would fault it for violating our constitutional separation of powers.

Thus, I am not much troubled by the Court's willingness to presume legislative intent. What does trouble me is the cavalier way the Court treated the evidence of actual intent in Underwood and its reluctance to consider evidence rebutting the reenactment presumption. The Court belittled rather than analyzed the position taken by the 1985 House committee report that the statute had been misinterpreted by the lower court opinions. Committee reports are generally considered authoritative, ${ }^{262}$ and I do not see why the House report should not have been entitled to at least some consideration by the Court. ${ }^{263}$ Indeed, there is evidence that some members of the 1980 Congress intended that the standard fall somewhere between reasonableness and automatic fee awards. The original Senate bill in 1979 would have awarded fees automatically; the Department of Justice sought an amendment to impose fees only when the Government action was "arbitrary, frivolous, unreasonable, or groundless"; the Senate Judiciary Committee adopted a compromise position in the "substantially justified" test, rejecting both the Government's test and a test of "reasonable justification."264 To be sure, the committee reports for the 1980 statute support Underwood's interpretation, but my point is that the Court blatantly ignored actual legislative expectations. There are arguments to be made on both sides about the intent of Congress in

262. Note that Justice Scalia authored the Undenwood decision. Justice Scalia has openly expressed his disdain for reliance on committee reports to interpret statutes. See Hirschey v. FERC, 777 F.2d 1, 7-8 (D.C. Cir. 1985) (Scalia, J., concurring) (same EAJA issue as in Underwood). Though some lower court judges find his position tenable, there is no indication that his view is widely shared on the Supreme Court. Cf. Farber \& Frickey, Legislative Intent and Public Choice, 74 VA. L. REv. 423 (1988) (criticizing Justice Scalia's position).

263. See Undenwood, $108 \mathrm{~S}$. Ct. at 2556-57 (Brennan, J., concurring in the judgment). The Government argued that sponsors of the EAJA "renounced" portions of the House report on the floor of the House and Senate. Petitioner's Brief at 17-18, Underwood (No. 86-1512). This was a pretty outrageous argument, because the portion questioned did not relate to the test being considered in Underwood. As one of the questioners said, "[t]he committee report . . . should not be interpreted to suggest that a finding of an agency action that was not supported by substantial evidence would automatically entitle a prevailing party to fees." According to the questioner, this was "the only error I found in the report." 131 CoNG. REc. H4763 (daily ed. June 24, 1985); see Respondents' Brief at 26-27, Underwood (No. 86-1512).

264. S. REP. No. 253, 96th Cong., 1st Sess. 2-3 (1979); see Underwood, 108 S. Ct. at 2556 (Brennan, J., concurring in the judgment). In the House hearings on the Senate bill, Senator DeConcini (one of the sponsors) agreed with the statement that "substantially' justified would be more difficult for the agency or department to meet, than 'reasonable." 'Award of Attorney's Fees Against the Federal Government: Hearings on S. 265 Before the Subcomm. on Courts, Civil Liberties, and the Administration of Justice of the House Comm. on the Judiciary, 96th Cong., 2d Sess. 38 (1980): But see 125 CoNG. Rec. 21435 (1979) (earlier statement of Sen. DeConcini articulating test in terms of reasonableness). 
1985, or even 1980. My problem with Underwood, and some of the other legislative inaction cases, ${ }^{265}$ is that the Court short-circuited those arguments by its reliance on the presumption.

\section{The Presumption of Correctness (Reformulated) and Patterson}

Given my normative problems with the legislative inaction cases, I should urge the following refined approach: The presumption of correctness should apply for a building block interpretation; "so long as those hurt by the interpretation have had some meaningful access to the legislative process. A building block interpretation must be one which is not only authoritative and vertically coherent (reliance), but also horizontally coherent (consistent with current policies). The presumption of correctness can be rebutted by persuasive evidence that Congress in fact has disapproved of the building block interpretation. Consider the issues in Patterson under this approach. Is Runyon a building block interpretation? If so, is the presumption of correctness rebutted by contrary evidence of actual legislative intent?

Whether or not Runyon was originally a correct interpretation of section 1981, it has become a building block one, given the descriptive and normative considerations set out above. First, and most important, its interpretation is both vertically and horizontally coherent. Runyon flowed naturally from the Court's interpretation of section 1982 in Alfred H. Mayer (which was the real turning point) and the experience in the lower courts, and the Court has followed or assumed that interpretation several times in the last decade. Hundreds of private lawsuits have been brought under section 1981, and the Department of Justice in Runyon had argued that it favored the interpretation as a way of complementing the Government's enforcement of the desegregation mandate in education. ${ }^{266}$ The interpretation is also consistent with our overall legal and constitutional evolution in the last twenty years. Not only has the legal system remained committed to the antidiscrimination principle in education and employment, but the system has expanded upon it administratively (by denying tax benefits to schools that discriminate), legislatively (the Fees Act in 1976, the Pregnancy Discrimination Act in 1978, the Restoration Act in 1988), and judicially (Bob Jones). That commitment has also been a commitment to providing a "multiplicity" of remedies for victims of discrimination. In short, Runyon's result is consistent at many levels

265. See, e.g., United States v. Shreveport Grain \& Elev. Co., 287 U.S. 77, 83-84 (1933) (refusing to rebut presumption of acquiescence in administrative interpretations, despite contrary statements in both House and Senate committee reports).

266. Brief for the United States as Amicus Curiae at 2-3, Runyon (No. 75-62). 
with previous and subsequent legal developments and "surely accords with the prevailing sense of justice today." 267

Second, there has been substantial public reliance on Runyon's interpretation. At the federal level, the best example is the Fees Act. In that statute, Congress assumed that section 1981 provided for private actions and sought to encourage such actions with counsel fee incentives. At a more general level, Congress has been encouraging expansive civil rights enforcement quite strongly. Indeed, 66 Senators and 118 Members of the House have filed a brief in Patterson asserting their continuing support for, and reliance on, the Runyon interpretation. ${ }^{268}$ The brief makes it clear that many legislators would consider overruling Runyon not only erroneous, but an interference in Congress' agenda, darkly hinting that the Restoration Act of 1988 ought to warn the Court not to interpret civil rights statutes narrowly. "To require the Congress to revisit this issue could jeopardize the closure and repose that we have obtained as a Nation on the issue of racial discrimination."269 At the state level, there is a similar consensus. Forty-seven states have joined in a brief arguing that state remedies for private discrimination would be left inadequate if Runyon were overruled. ${ }^{270}$

Third, but least important, there may have been some private reliance on Runyon. The petitioner in Patterson asserts that she waived her Title VII claims because she did not go through its procedural labyrinth, thinking that she could bring the same claims under section 1981,271 and there may be some other claimants in her position who would lose legal rights through no fault of their own if Runyon were overruled with retroactive effect. Other reliance arguments may exist in this case, ${ }^{272}$ but in my view they are hard to quantify, and the public reliance arguments are far more persuasive.

If Runyon is a building block case, as I think it is, the burden was on Congress to overturn it if it disagreed with its result. Obviously, Congress has not overturned Runyon, and the presumption of its correctness applies in full force. If anything, the presumption is strengthened by Congress' reliance on the interpretation when it enacted the

267. Runyon, 427 U.S. at 191 (Stevens, J., concurring).

268. Congress' Brief, supra note 8, at 20-28.

269. Id. at 6.

270. Brief of Forty-Seven States, the District of Columbia, and Three Territories as Amici Curiae in Support of Petitioner at 1-3, Patterson (No. 87-107).

271. Petitioner's Brief, supra note 8, at 105.

272. E.g., Congress' Amicus Brief, supra note 8, at 18 (parents have relied on the decision by putting their children in private schools with the assurance that they would remain desegregated). 
Fees Act in 1976. The presumed correctness of Runyon ought to preserve the precedent unless it was a clearly incorrect interpretation. I have undertaken no independent research on this issue but am impressed by arguments that Runyon was not clearly erroneous. ${ }^{273}$

In short, if the Court wants to make sense of, and be faithful to, its legislative inaction precedents, Patterson is a classic case for their invocation. Indeed, I consider Patterson to be a more appealing case for the invocation of legislative inaction arguments than either Monessen or Underwood. Unlike Monessen, Patterson involves not only a longstanding and well-settled statutory interpretation, but one that is consistent with our society's evolving law. Unlike Underwood, Patterson involves a statutory interpretation that not only appears to enjoy continued support in Congress, but is one upon which Congress relied when it passed the Fees Act in 1976. Given the Court's own vow to "treat all litigants equally" when it asked for new briefs in Patterson, ${ }^{274}$ it should reaffirm Runyon's building block interpretation.

\section{CONCLUSION}

It is noteworthy that a central theme running through all three of the articles in this Symposium on Patterson is the dynamic nature of statutory interpretation. ${ }^{275} \mathrm{I}$ have defended this general proposition in earlier articles, ${ }^{276}$ and this article explores its relationship to legislative inaction arguments. From my perspective, the main legisprudential issue raised by these legislative inaction cases is how much we want to emphasize vertical continuity in legal rules, at the expense of flexibility in our system of evolving law. While the Anglo-American legal tradition is one that has placed a great value on vertical continuity in the law, that emphasis is somewhat less tenable today, when most of our law is agency-made rather than judge-made, and when society and its problems change at an ever-increasing pace. The primary threat to law's integrity in modern times is obsolescence rather than unpredict-

273. See Farber, supra note 68 , at 18 ; Petitioner's Brief, supra note 8 , at 5-71; see also Aleinikoff, supra note 161, at 95 .

274. Patterson, $108 \mathrm{~S}$. Ct. at 1421 . The four Justices dissenting from the request had charged that the Court ought not disturb a precedent protecting civil rights. $108 \mathrm{~S}$. Ct. at 1422-23 (Stevens, J., dissenting).

275. Aleinikoff, supra note 161, uses Patterson as a way to contrast history-focused "archeological" modes of statutory interpretation with a current-policy focused "nautical" mode, which the author endorses. Farber, supra note 68, uses the ambiguous evidence of historical intent in Patterson to show how even conventional statutory interpretation necessarily considers current policies.

276. Eskridge, Dynamic Statutory Interpretation, supra note 161, articulates and defines the general proposition, and Eskridge, Politics Without Romance, supra note 206, presents economic arguments for the proposition. This article and Eskridge, Overruling Statutory Precedents, supra note 9, apply dynamic interpretation insights to important doctrinal issues. 
ability and instability. ${ }^{277}$ In my opinion, our aspiration for coherence in the law should concentrate more on the horizontal coherence of current policies, and less on the vertical coherence of a single policy backwards in time. Congress itself is the most legitimate institution for achieving greater horizontal coherence. But given the structural inertia and biases of the legislature, it is those who interpret and implement statutes - agencies, the executive, courts - that have the primary burden of fostering horizontal coherence.

Read broadly, the legislative inaction cases threaten to exacerbate the problems of inertia and bias - and obsolescence - in our system of government. The rhetoric used by the Supreme Court in these cases can be read to ossify statutory interpretations that have no other virtue save longevity. But the cases need not be read so broadly. A more sensible reading of the cases suggests that some statutory interpretations are building blocks, upon which future law can be constructed, while other interpretations may be aberrations overtaken by subsequent developments in law and society. As a descriptive theory, the theory of presumed correctness explains the cases and ameliorates the problem of obsolescence.

But the theory of presumed correctness for building block interpretations is not satisfying as a normative theory, and I believe several of the Court's legislative inaction cases are wrong. If a narrow, wellorganized group wins a favorable interpretation - perhaps by fortuity, perhaps by sheer perseverance - from the courts, an agency, or the executive, and then builds its own reliance interests and trumpets it to Congress, should the courts or agency not be able to change its mind later, when problems with the interpretation become manifest? I don't see why not, and hence I believe Flood v. Kuhn was wrongly decided. If an early interpretation becomes boilerplate law, cited with approval by courts and even committee reports because of its age and not because of its persuasiveness, should that interpretation not be subject to reevaluation if it becomes seriously inconsistent with current values? I don't see why not, and hence I believe Monessen was wrongly decided.

As a normative proposition, the legislative inaction precedents I should not have joined - Catholic Bishop of Chicago and Snyder, as well as Flood and Monessen - are those where the Court has invoked the presumption of correctness for interpretations having strong claims of vertical.continuity and (sometimes) private reliance, and weak claims of horizontal continuity and current fairness. For such

277. See generally G. Calabresi, A Common LAW for the Age of Statutes (1982). 
interpretations, I ürge a relaxation of the presumption of correctness. Private reliance interests can be protected in such cases by changing the interpretation prospectively, perhaps with a time period for private persons to adapt to the new rule. As for the virtues of vertical continuity, an interpretation that persists over time, yet becomes increasingly inconsistent with the surrounding legal terrain, does not have the unambiguous blessing of tradition and often ought to yield to current values and policies. 
APPENDIX 1: ACQUIEscence CASES (1961-1988)

This appendix collects the main Supreme Court cases decided between 1961 and 1988 in which the Court considered the argument that Congress acquiesced in a judicial, executive, or agency interpretation. Cases are included only if the Court's opinion, or a concurring or dissenting opinion, emphasized the argument. There is no claim that this is a complete listing, therefore. Where this appendix cites to a dissenting or special concurring opinion, the citation is to arguments not accepted by the Court.

\section{A. Judicial Interpretations $\dagger$ Finding Acquiescence}

Monessen Southwestern Ry. v. Morgan, 108 S. C.t. 1837, 1843-44 (1988) (lower court interpretation).

United States v. Johnson, 107 S. Ct. 2063, 2066 \& n.6 (1987).

Johnson v. Transportation Agency, Santa Clara County, California, 107 S. Ct. 1442, 1450 \& n.7 (1987).

Square D Co. v. Niagara Frontier Tariff Bureau, 476 U.S. 409, 420 (1986).

NLRB v. International Longshoremen's Association, 473 U.S. 61, 84 (1985).

Southern Motor Carriers Rate Conference, Inc. v. United States, 471 U.S. 48, 55 n.18 (1985).

Herman \& MacLean v. Huddleston, 459 U.S. 375, 384-86 (1983) (lower court interpretation).

Merrill Lynch, Pierce, Fenner \& Smith, Inc. v. Curran, 456 U.S. 353, 381-82 (1982) (lower court interpretation).

Bloomer v. Liberty Mutual Insurance Co., 445 U.S. 74, 85 (1980) (lower court interpretation). See also Edmonds v. Compagnie Generale Transatlantique, 443 U.S. 256, 266-67 (1979).

Cannon v. University of Chicago, 441 U.S. 677, 703 (1979) (lower court interpretation).

Blue Chip Stamps v. Manor Drug Stores, 421 U.S. 723, 732-33 (1975) (lower court interpretation).

Gulf Oil Corp. v. Copp Paving Co., 419 U.S. 186, $200-01$ (1974) (lower court interpretation).

Flood v. Kuhn, 407 U.S. 258, 280-85 (1972).

Laird v. Nelms, 406 U.S. 797, 802 (1972).

$\dagger$ Acquiescence arguments based upon lower federal court interpretations are noted by a parenthetical to that effect. Otherwise, the arguments are based upon Șupreme Court.opinions. 
Canada Packers, Ltd. v. Atchinson, Topeka \& Santa Fe Ry., 385 U.S. 182, 184 (1966).

Gillespie v. United States Steel Corp., 379 U.S. 148, 154-55 (1964).

Blau v. Lehman, 368 U.S. 403, 412-13 (1962) (lower court interpretation).

Monroe v. Pape, 365 U.S. 167, 186-87 (1961).

\section{Finding No Acquiescence}

Arkansas Best Corp. v. Commissioner, 108 S. Ct. 971, 977 n.7 (1988) (lower court interpretation).

Commissioner v. Fink, 107 S. Ct. 2729, 2736-38 (1987) (Stevens, J., dissenting) (lower court interpretation); see McNally v. United States, 107 S. Ct. 2875, 2890 (1987) (Stevens, J., dissenting); Citicorp Industrial Credit, Inc. v. Brock, 107 S. Ct. 2694, 2703-04 (1987) (Stevens, J., dissenting).

Shearson/American Express, Inc. v. McMahon, 107 S. Ct. 2332, 2342-43 (1987).

United States v. Mendoza-Lopez, 107 S. Ct. 2148, 2154 (1987) (lower court interpretation).

Heckler v. Day, 467 U.S. 104, 125-28 (1984) (Marshall, J., dissenting) (lower court interpretation).

Rodriguez v. Compass Shipping Co., 451 U.S. 596, 614-16 (1981) (one lower court interpretation).

Aaron v. SEC, 446 U.S. 680, 693-94 \& n.11 (1980) (lower court and SEC interpretation).

International Brotherhood of Teamsters v. United States, 431 U.S. 324, 390-94 (1977) (Marshall, J., concurring in part and dissenting in part) (lower court interpretation).

Barrett v. United States, 423 U.S. 212, 223-24 \& n.8 (1976).

Blonder-Tongue Laboratories, Inc. v. University of Illinois Foundation, 402 U.S. 313, 327 n.17 (1971).

Boys Markets, Inc. v. Retail Clerks Union Local 770, 398 U.S. 235 (1970).

Toussie v. United States, 397 U.S. 112, 120 (1970) (lower court interpretation).

United States v. Weldon, 377 U.S. 95, 101-02 (1964) (lower court interpretation).

James v. United States, 366 U.S. 213, 220-21 (1961) (plurality opinion). 


\section{B. Executive and Agency Interpretations}

\section{Finding Acquiescence}

School Board v. Arline, 107 S. Ct. 1123, 1126-27 (1987).

Wright v. City of Roanoke Redevelopment \& Housing Authority, 107 S. Ct. 766, 774 (1987).

Commodity Futures Trading Commission v. Schor, 478 U.S. 833 (1986).

United States v. Riverside Bayview Homes, Inc., 474 U.S. 121, 137 (1985).

SEC v. Jerry T. O’Brien, Inc., 467 U.S. 735, 745-47 (1984).

Grove City College v. Bell, 465 U.S. 555, 568 \& n.19 (1984).

Guardians Association v. Civil Service Commission, 463 U.S. 582, 593 \& n.14 (1983) (White, J.); see 463 U.S. at 616-24 (Marshall, J., concurring).

Bob Jones University v. United States, 461 U.S. 574, 599-602 (1983).

North Haven Board of Education v. Bell, 456 U.S. 512, 535 (1982).

NLRB v. Hendricks County Rural Electric Membership Corp., 454 U.S. 170, 187-90 (1981).

United States v. Clark, 454 U.S. 555, 564 (1982).

Haig v. Agee, 453 U.S. 280, 300-01 (1981).

CBS, Inc. v. FCC, 453 U.S. 367, 383-85 (1981).

Dames \& Moore v. Regan, 453 U.S. 654, 678-82 (1981).

Alessi v. Raybestos-Manhattan, Inc., 451 U.S. 504, 519-21 (1981).

Equal Employment Opportunity Commission v. Associated Dry Goods Corp., 449 U.S. 590, 600 n.17 (1981).

Andrus v. Shell Oil Co., 446 U.S. 657, 673 \& n.12 (1980).

United States v. Rutherford, 442 U.S. 544, $554 \&$ n.10 (1979).

Board of Governors of Federal Reserve System v. First Lincolnwood Corp., 439 U.S. 234, 245-48, 251-52 (1978).

Blue Chip Stamps v. Manor Drug Stores, 421 U.S. 723, 732-33 (1975).

Chemehuevi Tribe of Indians v. FPC, 420 U.S. 395, 410 (1975).

Saxbe v. Bustos, 419 U.S. 65, $73-74$ (1974).

NLRB v. Bell Aerospace Co., 416 U.S. 267, 287-88 (1974).

Red Lion Broadcasting Co. v. FCC, 395 U.S. 367, 381-82 (1969).

FTC v. Flotilla Products, Inc., 389 U.S. 179, 189-90 (1967).

Zemel v. Rusk, 381 U.S. 1, 11-12 (1965). 
Sperry v. Florida, 373 U.S. 379, 388-95 (1963).

Boesche v. Udall, 373 U.S. 472, 483 (1963).

Paul v. United States, 371 U.S. 245, 257-59 (1963).

Power Reactor Development Co. v. International Union of Electric, Radio \& Machine Workers, 367 U.S. 396, 408-09 (1961).

Brotherhood of Maintenance of Way Employees v. United States, 366 U.S. 169, 179 (1961).

\section{Finding No Acquiescence}

Motor Vehicle Manufacturers Association v. State Farm Mutual Automobile Insurance Co., 463 U.S. 29, 45-46 (1983).

Rowan Companies v. United States, 452 U.S. 247, 258-62 (1981).

Aaron v. SEC, 446 U.S. 680, 694 n.11 (1980).

Southeastern Community College v. Davis, 442 U.S. 397, 406-12 (1979).

SEC v. Sloan, 436 U.S. 103, 121 (1978).

Burns v. Alcala, 420 U.S. 575, 585-86 (1975).

Morton v. Ruiz, 415 U.S. 199, 212-30 (1974).

Zuber v. Allen, 396 U.S. 168, 185-93 (1969).

Toussie v. United States, 397 U.S. 112, 120 (1970).

NLRB v. Radio \& Television Broadcast Engineers Local 1212, 364 U.S. 573 (1961). 
APPENDIX 2: REENACTMENT CASES (1961-1988)

This appendix collects Supreme Court cases decided between 1961 and 1988 in which the Court considered the argument that Congress had ratified a judicial or administrative interpretation when it reenacted the statute without change. Cases are included only if the Court's opinion, or a concurring or dissenting opinion, emphasizes the argument. There is no claim that this is a complete listing, therefore. Where this appendix cites to a dissenting or specially concurring opinion, the citation is to arguments not accepted by the Court.

\section{A. Judicial Interpretations $\ddagger$}

Ratification by Reenactment

Pierce v. Underwood, 108 S. Ct. 2541, 2550-51 (1988) (lower court interpretation).

Midlantic National Bank v. New Jersey Department of Environmental Protection, 474 U.S. 494, 501 (1986) (lower court interpretation). See also Kelly v. Robinson, 479 U.S. 36 (1986).

Lindahl v. Office of Personnel Management, 470 U.S. 768, 782-85 \& n.15 (1985) (lower court interpretation).

Commissioner v. Engle, 464 U.S. 206, 225 (1984) (lower court interpretation).

Hillsboro National Bank v. Commissioner, 460 U.S. 370, 401-02 (1983) (lower court interpretation).

Herman \& MacLean v. Huddleston, 459 U.S. 375, 384-86 (1983) (lower court interpretation).

Merrill Lynch, Pierce, Fenner \& Smith, Inc. v. Curran, 456 U.S. 353, 381-82 (1982) (lower court interpretation).

Standefer v. United States, 447 U.S. 10, 18-19 \& n.11 (1980) (lower court interpretation).

Bloomer v. Liberty Mutual Insurance Co., 445 U.S. 74, 85 (1980) (lower court interpretation).

Owen Equipment \& Erection Co. v. Kroger, 437 U.S. 365, 373-74 \& n.16 (1978).

Lorillard v. Pons, 434 U.S. 575, 580 (1978) (statement of rule).

Douglas v. Seacoast Products, Inc., 431 U.S. 265, 279 (1977).

Franks v. Bowman Transportation Co., 424 U.S. 747, 771 (1976) (lower court interpretation).

$\ddagger$ Reenactment arguments based upon lower federal court interpretations will be denoted as such. Otherwise, assume that the reenactment argument is based upon a Supreme Court decision. 
United States v. American Building Maintenance Industries, 422 U.S. 271, 279-81 (1975).

Albemarle Paper Co. v. Moody, 422 U.S. 405, 414 n.8 (1975) (lower court interpretation).

Georgia v. United States, 411 U.S. 526, 533 (1973).

Deepsouth Packing Co. v. Laitram Corp., 406 U.S. 518, 530 \& n.10 (1972) (lower court interpretation).

Snyder v. Harris, 394 U.S. 332, 339 (1969).

No Ratification by Reenactment

McLaughlin v. Richland Shoe Co., 108 S. Ct. 1677, 1681 n.8 (1988).

Heckler v. Day, 467 U.S. 104, 125-28 (1984) (Marshall, J., dissenting) (lower court interpretation).

South Carolina v. Regan, 465 U.S. 367, 392 n.9 (1984) (O’Connor, J., concurring in the judgment).

Dickman v. Commissioner, 465 U.S. 330, 346-48 (1984) (Powell, J., dissenting) (lower court interpretation).

Rodriguez v. Compass Shipping Co., 451 U.S. 596, 614-15 (1981) (single lower court decision).

Mohasco Corp. v. Silver, 447 U.S. 807, 829-32 (1980) (Blackmun, J., dissenting) (lower court interpretation).

Aaron v. SEC, 446 U.S. 680, 694 n.11 (1980).

International Brotherhood of Teamsters v. United States, 431 U.S. 324, 391-93 \& n.24 (1977) (Marshall, J., dissenting) (lower court interpretation).

Zenith Radio Corp. v. Hazeltine Research, Inc., 401 U.S. 321, 335$36 \mathrm{n} .7$ (1971) (lower court interpretation).

United States v. Powell, 379 U.S. 48, 55 n.13 (1964) (lower court interpretation).

Commissioner v. Bilder, 369 U.S. 499 (1962) (lower court interpretation).

James v. United States, 366 U.S. 213, 220-21 (1961) (plurality opinion).

B. Executive and Agency Interpretations

Ratification by Reenactment

City of Pleasant Grove v. United States, 107 S. Ct. 794, 798 n.9 (1987).

Clarke v. Securities Industries Association, 479 U.S. 388 (1987). 
Commodity Futures Trading Commission v. Schor, 478 U.S. 833 (1986).

Young v. Community Nutrition Institute, 476 U.S. 974 (1986).

FDIC v. Philadelphia Gear Corp., 476 U.S. 428, 437 (1986).

United States v. Clark, 454 U.S. 555, 563-64 (1982).

Haig v. Agee, 453 U.S. 280, 297-98, 300-01 (1981).

Board of Education of City School District of New York v. Harris, 444 U.S. 130, 148-49 (1979).

Zenith Radio Corp. v. United States, 437 U.S. 443, 457 (1978).

United States v. Board of Commissioners of Sheffield, Alabama, 435 U.S. 110, 133-34 (1978).

Lorillard v. Pons, 434 U.S. 575, 480 (1978) (statement of rule).

Don E. Williams Co. v. Commissioner, 429 U.S. 569, 575-77 (1977).

Federal Energy Administration v. Algonquin SNG, Inc., 426 U.S. 548, 567-71 (1976).

Chemehuevi Tribe of Indians v. FPC, 420 U.S. 395, 410 (1975).

NLRB v. Bell Aerospace Co., 416 U.S. 267, 275 (1974).

Fribourg Navigation Co. v. Commissioner, 383 U.S. 272, 283 (1966).

Zemel v. Rusk, 381 U.S. 1, 11-12 (1965).

Commissioner v. Noel's Estate, 380 U.S. 678, 682 (1965).

No Ratification by Reenactment

Lukhard v. Reed, 107 S. Ct. 1807, 1814 (1987) (plurality opinion).

Aaron v. SEC, 446 U.S. 680, 694 n.11 (1980).

SEC v. Sloan, 436 U.S. 103, 119-20 (1978).

Leary v. United States, 395 U.S. 6, 24-25 (1969).

Commissioner v. Stidger, 386 U.S. 287, 292-95 (1967).

FPC v. Union Electric Co., 381 U.S. 90, 110-11 n.30 (1965). 
Appendix 3: Rejected Proposal Cases (1961-1988)

This appendix collects Supreme Court cases decided between 1961 and 1988 in which the Court considered the argument that it should not interpret a statute to embrace a meaning rejected by Congress (usually through a conference committee), or by one House of Congress (voting down a proposed amendment or bill), or by a committee of Congress (usually by failing to report a proposed bill). Cases are included only if the Court's opinion, or a concurring or dissenting opinion, emphasizes the argument. There is no claim that this is a comprehensive listing, therefore. Where this appendix cites to a dissenting or specially concurring opinion, the citation is to arguments not accepted by the Court.

\section{A. Failure of Bicameral Agreement or Presentment}

\section{Inferring Significance}

Tanner v. United States, 107 S. Ct. 2739, 2748-50 (1987).

INS v. Cardoza-Fonseca, 107 S. Ct. 1207, 1219 (1987).

United States v. Riverside Bayview Homes, Inc., 474 U.S. 121, 137-38 (1985).

Bennett v. Kentucky Department of Education, 470 U.S. 656, 665 n.3 (1985).

Escondido Mutual Water Co. v. LaJolla Band of Mission Indians, 466 U.S. 765, 787 (1984).

Pacific Gas \& Electric Co. v. State Energy Resources Conservation \& Development Commission, 461 U.S. 190, 219-20 (1983).

Illinois v. Abbott \& Associates, Inc., 460 U.S. 557, 568-70 (1983).

Watt v. Alaska, 451 U.S. 259, 264 n.8 (1981).

Board of Education of City School District of New York v. Harris, 444 U.S. 130, 148-49 (1979).

New York Telephone Co. v. New York State Department of Labor, 440 U.S. 519, 544 n.44 (1979).

Regents of the University of California v. Bakke, 438 U.S. 265, 346-47 (1978) (Brennan, J., concurring in part).

Albemarle Paper Co. v. Moody, 422 U.S. 405, 414 n.8 (1975).

Gulf Oil Corp. v. Copp Paving Co., 419 U.S. 186, 199-200 (1974).

Moor v. County of Alameda, 411 U.S. 693, 707-10 (1973), overruled, Monell v. Department of Social Services, 436 U.S. 658 (1978).

S \& E Contractors, Inc. v. United States, 406 U.S. 1, 11-12 (1972).

NLRB v. Gissel Packing Co., 395 U.S. 575, 598 (1969). 
Waterman Steamship Corp. v. United States, 381 U.S. 252, 268-69 (1965).

Sinclair Refining Co. v. Atkinson, 370 U.S. 195, 205-10 (1962), overruled, Boys Markets, Inc. v. Retail Clerks Union, Local 770, 398 U.S. 235 (1970).

Monroe v. Pape, 365 U.S. 167, 188-89 (1961), overruled, Monell v. Department of Social Services, 436 U.S. 658 (1978).

\section{Inferring No Significance}

Communications Workers of America v. Beck, 108 S. Ct. 2641, 2654-55 (1988).

Wright v. City of Roanoke Redevelopment \& Housing Authority, 479 U.S. 418, 475-80 (1987) (O’Connor, J., dissenting).

Pattern Makers' League of North America v. NLRB, 473 U.S. 95, 121-23 (1985) (Brennan, J., dissenting).

Kremer v. Chemical Construction Corp., 456 U.S. 461, 494-97 (1982) (Blackmun, J., dissenting).

Mohasco Corp. v. Silver, 447 U.S. 807, 829-32 (1980) (Blackmun, J., dissenting).

Nachman Corp. v. Pension Benefit Guaranty Corp., 446 U.S. 359, 392-93 (1980) (Stewart, J., dissenting).

Whirlpool Corp. v. Marshall, 445 U.S. 1, 16-21 (1980).

NLRB v. Catholic Bishop of Chicago, 440 U.S. 490, 512-14 (1979) (Brennan, J., dissenting).

International Brotherhood of Teamsters v. Daniel, 439 U.S. 551, 563-64 (1979). (1978).

Monell v. Department of Social Services, 436 U.S. 658, 664-95

Federal Energy Administration v. Algonquin SNG, Inc., 426 U.S. 548, 568-70 (1976).

Burns v. Alcala, 420 U.S. 575, 585-86 (1975).

Linden Lumber Division, Summer \& Co. v. NLRB, 419 U.S. 301, 312 (1974) (Stewart, J., dissenting).

Trbovich v. UMW, 404 U.S. 528, 535-36 (1972).

United States v. International Minerals \& Chemical Corp., 402 U.S. 558, 562-63 (1971).

Boys Markets, Inc. v. Retail Clerks Union, Local 770, 398 U.S. 235, 261 (1970) (White, J., dissenting).

National Woodwork Manufacturers Association v. NLRB, 386 U.S. $612,631-32$ (1967). 
B. Failure of Proposal on the Floor of One House

Inferring Significance

Thompson v. Thompson, 108 S. Ct. 513, 518-19 (1988).

Burlington Northern Railroad v. Brotherhood of Maintenance of Way Employes, 107 S. Ct. 1841, 1848 (1987).

Local 28, Sheet Metal Workers International Association v. Equal Employment Opportunity Commission, 478 U.S. 421 (1986) (plurality opinion).

United States v. Riverside Bayview Homes, Inc., 474 U.S. 121, 137 (1985).

Grove City College v. Bell, 465 U.S. 555, 568 \& n.19 (1984).

Guardians Association v. Civil Service Commission, 463 U.S. 582, 620 (1983) (Marshall, J., concurring in part).

North Haven Board of Education v. Bell, 456 U.S. 512, 531-35 (1982).

Federal Election Commission v. Democratic Senatorial Campaign Committee, 454 U.S. 27, 35-36 \& n.12 (1981).

Universities Research Association, Inc. v. Coutu, 450 U.S. 754, 777-80 (1981).

FCC v. WNCN Listeners Guild, 450 U.S. 582, $597 \&$ n.33 (1981).

Hutto v. Finney, 437 U.S. 678, 698 n.31 (1978).

Runyon v. McCrary, 427 U.S. 160, 174 n.11 (1976).

Train v. Colorado Public Interest Research Group, Inc., 426 U.S. 1, 17-22 (1976).

Bradley v. Richmond School Board, 416 U.S. 696, 716 n.23 (1974).

Alexander v. Gardner-Denver Co., 415 U.S. 36, 48 n.9 (1974).

Rodrigue v. Aetna Casualty \& Surety Co., 395 U.S. 352, 358-59 (1969).

United States v. Jackson, 390 U.S. 570, 575-76 \& nn.10-11 (1968).

Gardner v. Toilet Goods Association, 387 U.S. 167, 181-82 (1967) (plurality opinion).

FPC v. Union Electric Co., 381 U.S. 90, 108 \& n.28 (1965).

Van Dusen v. Barrack, 376 U.S. 612, 635-37 (1964)

Arizona v. California, 373 U.S. 546, 580-81 (1963), decree entered, 383 U.S. 268 (1966), order amended, 466 U.S. 144 (1984).

\section{Inferring No Significance}

Agency Holding Corp. v. Malley-Duff \& Associates, Inc., 107 S. Ct. 2759, 2766 (1987).

Offshore Logistics, Inc. v. Tallentire, 477 U.S. 207 (1986). 
Firefighters Local 1784 v. Stotts, 467 U.S. 561, 619-20 (1984) (Blackmun, J., dissenting).

City of Milwaukee v. Illinois, 451 U.S. 304, 332 n.24 (1981).

Potomac Electric Power Co. v. Director, Office of Workers' Compensation Programs, 449 U.S. 268, 276 n.14 (1980).

NLRB v. Catholic Bishop of Chicago, 440 U.S. 490, 514-16 (1979) (Brennan, J., dissenting).

Group Life \& Health Insurance Co. v. Royal Drug Co., 440 U.S. 205, 222-23 n.29 (1979).

Monell v. Department of Social Services, 436 U.S. 658, 664-95 (1978).

Connell Construction Co. v. Plumbers \& Steamfitters Local 100, 421 U.S. 616, 652-55 (1975) (Stewart, J., dissenting).

United States v. Enmons, 410 U.S. 396, 414-17 (1973) (Douglas, J., dissenting).

Magnesium Casting Co. v. NLRB, 401 U.S. 137, 142 (1971).

NLRB v. C \& C Plywood Corp., 385 U.S. 421, 426-29 (1967).

United States v. California, 381 U.S. 139, 158-60 \& n.23 (1965), supplemented by 382 U.S. 448 (1966) and 432 U.S. 40 (1977).

James v. United States, 366 U.S. 213, 220-21 (1961) (plurality opinion).

\section{Failure of Proposal To Escape Committee}

\section{Inferring Significance}

Monessen Southwestern Ry. v. Morgan, 108 S. Ct. 1837, 1844 n.8 (1988).

Landers v. National Railroad Passengers Corp., 108 S. Ct. 1440, 1442 (1988).

Norwest Bank Worthington v. Ahlers, 108 S. Ct. 963, 968 (1988).

K Mart Corp. v. Cartier, Inc., 108 S. Ct. 950, 958-59 (1988).

Heckler v. Day, 467 U.S. 104, 111-15 (1984).

Aloha Airlines, Inc. v. Director of Taxation, 464 U.S. 7, 13 n.7 (1983).

Bob Jones University v. United States, 461 U.S. 574, 600-01 (1983).

Baldridge v. Shapiro, 455 U.S. 345, 358 (1982).

Dames \& Moore v. Regan, 453 U.S. 654, 685-86 (1981).

CBS, Inc. v. FCC, 453 U.S. 367,384 n.9 (1981).

Carlson v. Green, 446 U.S. 14, 20 (1980). 
New York Telephone Co. v. New York State Department of Labor, 440 U.S. 519, 542-45 (1979) (plurality opinion).

Santa Clara Pueblo v. Martinez, 436 U.S. 49, 67-69 (1978).

Administrator, FAA v. Robertson, 422 U.S. 255, 264 (1975).

Blue Chip Stamps v. Manor Drug Stores, 421 U.S. 723, 732-33 (1975).

Chemehuevi Tribe of Indians v. FPC, 420 U.S. 395, 410 (1975).

Central Tablet Manufacturing Co. v. United States, 417 U.S. 673, 689-90 \& n.9 (1974).

Shea v. Vialpando, 416 U.S. 251, 264 n.12 (1974).

National Railroad Passenger Corp. v. National Association of Railroad Passengers, 414 U.S. 453, $459-61$ (1974).

Mattz v. Annett, 412 U.S. 481, 504-05 (1973).

Flood v. Kuhn, 407 U.S. 258, 280-83 (1972).

City of Greenwood v. Peacock, 384 U.S. 808, 834 (1966).

Fribourg Navigation Co. v. Commissioner, 383 U.S. 272, 283-86 (1966).

Brotherhood of Locomotive Engineers v. Chicago Rock Island \& Pacific Railroad, 382 U.S. 423 (1966).

United States v. Muniz, 374 U.S. 150, 155-56 (1963).

Wheeldin v. Wheeler, 373 U.S. 647, 652 (1963).

Blau v. Lehman, 368 U.S. 403, 411-12 (1962).

\section{Inferring No Significance}

Boyle v. United Technologies Corp., 108 S. Ct. 2510, 2520 \& n.1 (1988) (Brennan, J., dissenting).

Goodyear Atomic Corp. v. Miller, 108 S. Ct. 1704, 1712 (1988).

United States v. Wells Fargo Bank, 108 S. Ct. 1179, 1184 (1988).

Schneidewind v. ANR Pipeline Co., 108 S. Ct. 1145, 1153-54 (1988).

Basic, Inc. v. Levinson, 108 S. Ct. 978, 997 (1988) (White, J., concurring in part and dissenting in part).

Wimberly v. Labor \& Industrial Relations Commission, $107 \mathrm{~S}$. Ct. 821,826 (1987).

Hillsboro National Bank v. Commissioner, 460 U.S. 370, 421 \& n.32 (1983) (Stevens, J., dissenting).

Jefferson County Pharmaceutical Association v. Abbott Laboratories, 460 U.S. 150, 164-66 (1983) (Stewart, J., dissenting).

Trbovich v. UMW, 404 U.S. 528, 532-35 (1972). 
Blonder-Tongue Laboratories, Inc. v. University of Illinois Foundation, 402 U.S. 313, 342 n.37 (1971).

Red Lion Broadcasting Co. v. FCC, 395 U.S. 367, 381 \& n.11 (1969).

United States v. Southwestern Cable Co., 392 U.S. 157, 169-71 (1968).

United States v. Philadelphia National Bank, 374 U.S. 321, 379-81 (1963) (Harlan, J., dissenting).

United States v. Wise, 370 U.S. 405, 411 (1962). 